\title{
COMMENTS
}

\section{Due Process Rights of Participation in Administrative Rulemaking}

\author{
Evelyn R. Sinaiko ${ }^{\dagger}$
}

The applicability of procedural due process to administrative rulemaking proceedings is becoming an issue of some importance as administrative agencies take an ever greater role in deciding issues of widespread social impact. While much of the debate focuses on procedural rights beyond those of notice and comment participation, this Comment examines the need to recognize a due process right to notice and comment itself. The author argues that this problem is particularly pressing in light of section 553(a)(2) of the Administrative Procedure Act, which allows agencies to make many important policy decisions without any public participation.

In the early days of administrative law, agencies were regarded primarily as regulatory bodies rather than planners. They conducted their business largely through adjudication of individual cases, guided by legislative standards no inore concrete than a requirement that they act in the public interest. As agencies began to regulate a broader spectrum of public affairs, and openly took on planning and policymaking functions, the courts encouraged thein to employ ruleinaking procedures when dealing with issues of policy. ${ }^{1}$ This development reflects the idea that promulgating far-reaching policy decisions in proceedings limited to adversary parties is unfair; participation by many of those likely to be affected is restricted, even assuming involvement by some as amici or intervenors. It also reflects increasing awareness of the agencies' enormous power to determine the resolution of important social problems with little, if any, guidance from legislatures.

Despite the growing impact of agency decisions, few courts have been willing to inake public participation in rulemaking a constitutional requirement. In adjudicative proceedings the interests of individuals and the public have received increased judicial protection from arbi-

$\dagger$ B.A. 1968, Brandeis University; M.A. 1970, University of Chicago; J.D. 1975, Boalt Hall School of Law, University of California, Berkeley.

1. See NLRB v. Wyman-Gordon Co., 394 U.S. 759 (1969). In particular, see Justice Douglas' dissenting opinion, id. at 775 . 
trary agency action, but those same interests have received little protection from the courts in the context of agency rulemaking. As a result, many individuals and groups have been excluded from agencies' rulemaking deliberations. ${ }^{2}$ Often this lias gone uncliallenged. When it has been tested, courts have frequently used outdated distinctions and modes of analysis to justify their refusal to recognize a constitutional right to participate in agency rulemaking.

As the use of agency rulemaking procedures to make decisions of widespread impact grows, courts will face increasing pressure to require greater public participation in the decisionmaking process. This Comment argues that current case law contains a substantial foundation which courts may use to accommodate these pressures. Part I analyzes a theoretical framework which has served as the foundation for broadened participation through nonconstitutional judicial developments and which could serve as the basis for a constitutional right to participate. Part II discusses section 553(a)(2) of the federal Administrative Procedure Act (APA), ${ }^{3}$ which, insofar as it excepts rulemaking of enormous variety and social impact from any procedural requirements, may be the most urgent reason for recognizing such a constitutional right. Part III examines several recent precedents which may foreshadow explicit recognition of a due process right to participate in rulemaking. Part IV discusses what the limits and implications of the right to participate should be and briefly examines the issues of the constitutional adequacy of the notice and comment procedures of the APA.

I

The Right to Participate in Agency Rulemaking:

A THEORETTCAL APPROACH

\section{A. The Traditional Approach}

The fifth and fourteenth annendments impose the limitation of due process on the state whenever it acts to deprive individuals of life, liberty or property. This due process requirement has two facets. Procedurally, it ineans the state inay not deprive one of a protected property

2. The rulemaking provisions of the federal Administrative Procedure Act, 5 U.S.C. $\$ 553$ (1970) Theremafter cited as APA], generally require agencies to give notice of proposed rulemaking in the Federal Register and to allow participation of interested persons by submission of written comments. The agency may also allow oral presentation of argument if it deems it advisable or useful. However, the wide-ranging exceptions in the APA allow agencies to escape these requirements in many instances. See part II infra. Moreover, even those states which require state agencies to conduct rulemaking proceedings do not generally require the same of municipal and other local agencies. See, e.g., CAL. Gov'T CODE $\$ \S 11420-27$ (West 1966). Thus, a great deal of rulemaking nnay be done without any public participation.

3. 5 U.S.C. $\$ 553(\mathrm{a})(2)(1970)$. 
or liberty interest without notice and an opportunity to be heard. Substantively, the state nay not act arbitrarily. The procedural aspects of due process depend on the substantive protections to give thein meaning. In the absence of a substantive requirement of fairness, a hearing would be a pro forma exercise. ${ }^{4}$ Conversely, the requirements of notice and hearing reinforce the substantive guarantee by serving as a safeguard against arbitrary state action. The assumption is that by giving parties with sufficient interest in the outcome a chance to present evidence from their point of view, the government can best make an informed decision which considers all relevant factors. ${ }^{.}$

Although the substantive and procedural aspects of due process are interdependent, procedural due process has a narrower scope than its substantive counterpart. Generally, procedural requirements apply only to those state actions which affect a significant interest of one individual or of a small group and which depend on factual, rather than policy, determinations. The paradigm to which procedural due process applies is the court proceeding. The judicial system has evolved elaborate procedural mechanisms by which the individual may attack the factual justifications for sanctions or deprivations the state threatens to impose or enforce. These safeguards are necessary because of the decisionmaking methods inherent in the adjudicatory process. One person or a small group of people, often appointed rather than elected, make the decision. Deliberations leading to the decision are closed to the public. Moreover, since the decision affects important interests of only one or a small number of people, the consequences of arbitrary action will not directly affect the public at large and therefore will be subject to less public scrutiny. Procedural protections are further compelled by the assumptions that the individual has peculiar knowledge as to relevant facts, and has such a strong interest in the outcome that a failure to consider his viewpoint would be a denial of justice. ${ }^{\circ}$

4. Board of Regents of State Colleges v. Roth, 408 U.S. 564 (1972); see Goldberg v. Kelly, 397 U.S. 254 (1970).

5. The constitutional right to be heard is a basic aspect of the duty of government to follow a fair process of decisionmaking when it acts to deprive a person of his possessions .... Its purpose, more particularly, is to protect his use and possession of property from arbitrary encroachment . ...

Fuentes v. Shevin, 407 U.S. 67, 80-81 (1972); see Note, Procedural Due Process in Government Subsidized Housing, 86 HARv. L. REv. 880, $905-06$ (1973).

These procedural requirements also serve the more abstract purpose of "generating the feeling, so important to a popular government, that justice has been done." Joint Anti-Fascist Refugee Committee v. McGrath, 341 U.S. 123, 172 (1951) (Frankfurter, J., concurring); accord, Morrissey v. Brewer, 408 U.S. 471, 484 (1972) ("[F]air treatment in parole revocations will enhance the chance of rehabilitation by avoiding reactions to arbitrariness."). Justice Douglas, dissenting in part in Morrissey, also emphasized the role of procedural due process in fostering belief in the "rule of law." Id, at 499.

6. Within the judicial context, it is possible for particular cases to move closer 
Traditionally, however, procedural due process has been considered inapplicable to the legislative setting. Congress may pass laws affecting vital interests of large numbers of people without providing any procedural safeguards. While the laws must satisfy substantive due process requirements, ${ }^{7}$ the public has no right to participate directly in deliberations of the legislature. This can be explained in light of the distinctions between the legislative and judicial processes. As an elected body, the legislature, unlike the judiciary, is broadly representative and, at least theoretically, responsive to the will of the electorate. Its deliberations are generally open to public inspection and hence subject to public pressure. Because a large group of people acts as a decisionmaker, arbitrary action is less likely. Finally, legislative decisions generally affect inany people, so that any individual's view becoines less relevant to the outcoine. In sum, requirements of participation and hearing are not imposed because the legislative process itself provides sufficient protection against arbitrary government action. ${ }^{8}$

Agencies combine both legislative and judicial functions. Depending on the function being exercised, ${ }^{9}$ either the legislative or the adjudi-

to the legislative model. Complex class actions dealing with complicated policy as well as factual issues and affecting large numbers of people pose questions more similar to those dealt with by legislatures than those entertained by courts in simpler two-party adversary proceedings. See, e.g., Hobson v. Hansen, 269 F. Supp. 401 (D.D.C. 1967), aff'd sub nom. Smuck v. Hobson, 408 F.2d 175 (1969). However, strict procedural protections apply since the decisions are made in the judicial context. This suggests that the nonrepresentative nature of the decisionmaker is the most significant factor. Simce agencies are nonrepresentative, such a conclusion indicates that at least some procedural protections are called for in the rulemaking process, in spite of its legislative aspects. See text accompanying notes 25-39 infra.

7. The staudard of judicial review to be apphied in determining whether substantive due process is satisfied varies with the interest involved. Generaily, economic and social regulations must simply have a rational basis in fact. Laws affecting individual rights protected either implicitly or explicitly by the Constitution must pass a more searching standard of review. Compare, e.g., Carolene Products Co. v. United States, 323 U.S. 18 (1944), with Loving v. Virginia, 388 U.S. 1 (1967). See generally McCloskey, Economic Due Process and the Supreme Court: An Exhumation and Reburial, 1962 Sup. CT. Rev. 34 (1962); Comment, Developments in the Law-Equal Protection, 82 HARV. L. REv, 1065, 1077-87 (1969).

8. Also, the legislative process has other built-in procedural protections. Each bill must go through introduction, committee evaluation, debate and vote in two houses, and is, in addition, subject to executive veto. The checks and balances inherent in this process, as weil as those provided by political realities, should effectively prevent irrational legislative action. See Ratner, The Function of the Due Process Clause, $116 \mathrm{U}$. PA. L. Rev. 1048, 1080 (1968).

9. The APA reflects the assumption that a particular proceeding may clearly be defined as adjudication, in which the agency exercises its judicial function, or rulemaking, in which it acts legislatively. See 5 U.S.C. $\S \S 551(4)-(7)$ (1970). The procedure to be followed depends upon the label applied. This assumption has recently been attacked. See $1 \mathrm{~K}$. Davis, Administrative LaW Treatise $\$ 5.01$ at 285-86 (1958 ed. unless otherwise indicated) [hereinafter cited as K. Davis, with volume indicated]. See generally Robinson, The Making of Administrative Policy: Another Look at Rulemak- 
cative model of decisionmaking may apply. ${ }^{10}$ Rights of participation may vary greatly according to the type of proceeding.

In recent years, agency discretion in adjudicative situations has been severely limited by expanding the reach of procedural due process. In Goldberg v. Kelly, ${ }^{11}$ the Supreme Court held that a state could not deprive a welfare recipient of benefits without a pre-termination hearing on the issue of eligibility, even though the recipient was entitled to a full hearing later in the course of the administrative appeals process. ${ }^{12}$ In order to determine whether due process required a pretermination hearing, the Court balanced several considerations. ${ }^{13}$ The individual interest of the welfare recipient in continuing to receive the means by which to live until adjudged inehgible and the governmental interest in continuing to provide benefits to eligible individuals were weighed against the government's interest in having a summary pretermination cessation of benefits in order to avoid irrecoverable waste

ing, Adjudication and Administrative Procedure Reform, 118 U. PA. L. Rev. 485 (1970).

10. Under the APA, when an agency acts as a court would, it follows formal procedures. These include an impartial hearing examiner and an opportunity to present oral as well as written evidence, to present rebuttal evidence, and to cross-examine witnesses. 5 U.S.C. $\$ 556$ (d) (1970). Decisions must be made on the record, consisting of the transcript of the hearing and all papers filed in connection with it. Id. $\$ 556(\mathrm{e})$. These provisions are applicable to adjudications, $i d$. $\S 554$, and licensing proceedings, $i d$. $\$ 558$, as required by independent statutes. In addition, these procedures must be followed when statutes governing particular agencies require rules to be made on the record after opportunity for hearing. Id. $\$ 553(\mathrm{c})$. (This type of rulemaking will be referred to as formal rulemaking). However, in the case of formal rulemaking, the agency may allow only submission of written evidence if no prejudice will result. ld. $\S 556(\mathrm{~d})$.

When the same agency acts in a rulemaking capacity, it must follow the rulemaking procedures of section 553. Unless the agency decides to hold public hearings, the statute requires only notice of the proposed rule in the Federal Register and an opportunity to submit written comments. Id. $\$ 553(\mathrm{~b}),(\mathrm{c})$. No record of the agency's deliberations need be inade; the agency must, however, incorporate in the rule a statement of its basis and purpose. $1 d$. $\$ 553(\mathrm{c})$.

11. 397 U.S. 254 (1970).

12. This holding applies only where there are contested issues of fact. The Court did not reach the question of what procedural safeguards are necessary where "there are no factual issues in dispute or where the application of the rule of law is not intertwined with factual issues." ld. at 268 n.15. Regarding this issue, compare Mothers' and Children's Rights Org. v. Sterrett, 467 F.2d 797 (7th Cir. 1972) (opportumity for argument required), and Yee-Litt v. Richardson, 353 F. Supp. 996 (N.D. Cal. 1973) (fact-policy distinction unclear and unmanageable in welfare context), with Russo v. Kirby, 453 F.2d 548 (2d Cir. 1971) (no hearing on point of law).

13. The balancing test used by the Court was previously articulated in Cafeteria Workers Union v. McElroy, 367 U.S. 886, 895 (1961):

[C]onsideration of what procedures due process may require under any given set of circumstances must begin with a determination of the precise nature of the government function involved as well as of the private interest that has been affected by governmental action.

Cited in Goldberg v. Kelly, 397 U.S. at 263. 
of state funds and additional expense. ${ }^{14}$ The Court concluded that the "minimum procedural safeguards" were 1) adequate notice of termination and the reasons for it and 2) an effective opportunity to be heard. The latter safeguard includes the right to have counsel present if desired, to cross-examine adverse witnesses, to have an impartial hearing examiner, and to receive a statement of the reasons for his decision. ${ }^{15}$ Although the Court emphasized that "the pre-termination hearing need not take the form of a judicial or quasi-judicial trial," ${ }^{16}$ these safeguards are taken largely from the judicial context.

Simce Goldberg, similar procedural requirements have been extended to other administrative deprivations: pretrial license suspensions, ${ }^{17}$ parole revocation, ${ }^{18}$ eviction from public housing, ${ }^{19}$ and reductions in, as well as deprivations of, government benefits. ${ }^{20}$ In the course of this expansion of procedural due process, the courts exphicitly repudiated the "right-privilege" distinction, ${ }^{21}$ thereby broadening the range of individual interests protected from arbitrary agency action in adjudicative proceedings. ${ }^{22}$ In addition, the courts curbed potentially serious abuses of agency discretion by requiring procedural protections before

14. 397 U.S. at 262-66. The Court noted that, in some cases mvolving emergency situations, where a prior hearing would cause harm to the public greater than the protection such hearing would afford to the private interest, due process is not violated by summary state action. Id. at 263-64 n.10. Accord, Ewing v. Mytinger \& Casselberry, Inc., 339 U.S. 594 (1950). In Cafeteria Workers Union v. McElroy, 367 U.S. 886 (1961), which the Court cites in Goldberg as precedent for its balancing approach, the interest of a civilian cook in continued employment on a military base was held to be outweighed by the government interest in managing the internal operation of the base, thus enabling the government to revoke her security clearance without a hearing.

15. 397 U.S. at 267-71.

16. Id. at 266 .

17. Bell v. Burson, 402 U.S. 535 (1971).

18. Morrissey v. Brewer, 408 U.S. 471 (1972).

19. Escalera v. N.Y. City Housing Authority, 425 F.2d 853 (2d Cir. 1970); Caulder v. Durham Housing Authority, 433 F.2d 998 (4th Cir. 1970).

20. Hunt v. Edinunds, 328 F. Supp. 468 (D. Minn. 1971); Woodson v. Houston, 27 Mich. App. 239, 183 N.W.2d 465 (1970) (welfare benefits).

21. The right-privilege distinction listorically barred due process claims by recipients of government benefits or "privileges." See, e.g., Bailey v. Richardson, 182 F.2d 46 (D.C. Cir. 1950), aff'd by an equally divided Court, 341 U.S. 918 (1951) (per curiam). See generally $1 \mathrm{~K}$. Davis, supra note 9, $\$ \$ 7.11-.20$. The Court in Goldberg held welfare benefits to be a matter of entitlement for those eligible. Because they cannot be taken away arbitrarily, some procedural protections are required by due process. 397 U.S. 254, 261-63. See generally Van Alstyne, The Demise of the Right-Privilege Distinction in Constitutional Law, 81 HARv. L. REv. 1439 (1968).

22. However, in Board of Regents of State Colleges v. Roth, 408 U.S. 564 (1972), the Court made it clear that not all interests are protected by due process. In order to trigger the balancing process, the plaintiff must first demonstrate that he has a liberty or property interest within the purview of the fourteenth amendinent. To have a protected property interest, he must have more than an abstract need or desire for it; rather, there must be an entitlement based on a statute or an express or implied contract. In Morrissey v. Brewer, 408 U.S. 471 (1972), the Court found the interest in liberty to 
the agencies impair important individual interests, even though the administrative process has not run its course.

With few exceptions there has been no such expanded application of procedural due process to agency rulemaking. Courts have continued to adhere to the traditional position that, in agency rulemaking proceedings, due process does not require even minimal rights of participation. ${ }^{23}$ A widening gap between the rights of participation afforded to similarly affected individuals in different types of proceedings has resulted; those whose interests are subject to adjudicative procedures have extensive procedural rights, while those whose identical interests are threatened by rulemaking procedures may be denied any participation whatsover. ${ }^{24}$

be implicit in the parole system, and therefore required procedures to protect the paroleo from unwarranted parole revocation.

23. For examples of traditional analysis, see Albert v. Public Serv. Comm'n, 209 Md. 27, 120 A.2d 346 (1956); Senior Citizens League, Inc. v. Dep't of Social Security, 38 Wash. 2d 142, 168-70, 228 P.2d 478, 492-93 (1951) (en banc). These cases hold that neither notice nor liearing are required to be given to the affected public in rulemaking proceedings. While plaintiffs in both cases sought formal hearings, the looldings rcgarding notice imply that no form of participation is required before the policy is formulated.

24. A coinparison of the seminal cases of Londoner v. Denver, 210 U.S. 373 (1908) (special assessment requires opportunity for presentation of evidence and oral argument if needed) and Bi-Metallic Inv. Co. v. State Bd. of Equalization, 239 U.S. 441 (1915) (no learing required before forty percent increase in valuation of all Denver property) illustrates the disparate procedural requirements imposed in adjudicative and rulemaking proceedings although the individual interests affected are the same. It is true that the loolding in Bi-Metallic only reached the right to an evidentiary hearing in a rulemaking proceeding. The Court assumed for purposes of argument that the plaintiffs may have had sone opportunity to participate, since the time of meeting of the Board was fixed by law. Nonetheless, the case has often been cited to support a denial of a right to any type of participation. See, e.g., Hahn v. Gottlieb, 430 F.2d 1243, 1248-49 (1st Cir. 1970).

The distinction which Londoner and Bi-Metallic lighlight has, since Goldberg and its progeny, resulted in gross disparities in procedural protections, depending on the type of proceeding involved. For exainple, an agency may have to provide full rights of cross-examination and representation by counsel to a low-incoune tenant who is threatened with eviction from public housing. Yet, the same tenant, who may be effectively evicted by a proposed rent raise which he cannot afford, will lave no right to participato in the decision whether to allow the increase. Compare Caulder v. Durham Housing Authority, 433 F.2d 998 (4th Cir. 1970); Escalera v. City Housing Authority, 425 F.2d 853 (2d Cir. 1970); Lee v. Housing Authority, 119 N.J. Super. 72, 290 A.2d 160 (Union County Dist. Ct. 1972) (protected interest in low rent public lousing requires notice and full hearing before eviction) with Hahn v. Gottlieb, 430 F.2d 1243 (1st Cir. 1970); McKinney v. Washington, 442 F.2d 726 (D.C. Cir. 1970); People's Rights Org. v. Bethlehem Associates, 356 F. Supp. 407 (E.D. Pa. 1973) (no right to participate in decision to allow rent raise because no legal entitlement to low rents). Contra, Langevin v. Chenango Court, Inc., 447 F.2d 296, 300-01 (2d Cir. 1971). In Escalera, one plaintiff complained not of summary eviction procedures, but rather of imposition of additional "rent" charges as a penalty for breaking rules. The court lield that this plaintiff had a protected interest, since even small charges may have a great impact on the budgets of poor public housing tenants. 425 F.2d at 864; accord, Burr v. Municipal Housing Authority, 347 F. Supp. 1202 (S.D.N.Y. 1972), modified, 479 F.2d 1165 (2d Cir. 1973); cf. Roth. 
A rulemaking-adjudicative distinction does not justify this gap. The refusal to extend procedural due process to rulemaking cannot rest solely on the fact of delegation of power by the legislature. ${ }^{25}$ Although legislatures may delegate to agencies the power to determine basic issues of policy within a broad statutory framework, ${ }^{26}$ this does not mean that they may also delegate their immunity from procedural requirements. ${ }^{27}$ While under traditional analysis procedural due process restrictions do not apply to legislatures, the different characteristics of administrative agencies should compel a different result in the adıministrative context.

Except to the extent that they are appointed by elected officials, agencies, unlike legislatures, are not representative bodies. Administrators are chosen for their technical expertise. ${ }^{28}$ Selection criteria often emphasize experience gained by occupying positions of power

stein v. Wyman, 303 F. Supp. 339, 348 (S.D.N.Y. 1969), vacated and remanded, 398 U.S. 275 (1970).

For a similar dichotony in cases dealing with reduction in welfare benefits, compare Hunt v. Edwards, 328 F. Supp. 468 (D. Minn. 1971), and Woodson v. Houston, 27 Mich. App. 239, 183 N.W.2d 465 (Ct. App. 1970), with Provost v. Betit, 326 F. Supp. 920 (D. Vt. 1971).

25. Many courts have relied on the fact of delegation without further analysis. See Provost v. Betit, 326 F. Supp. 920, 923 \& n.3 (D. Vt. 1971); cf. Langevin v. Chenango Court, Inc., 447 F.2d 296, 301 (2d Cir. 1971). Their reasoning rests on the representative nature of the legislature. See Willapoint Oysters v. Ewing, 174 F.2d 676, 694 n.38 (9th Cir.), cert. denied, 338 U.S. 860 (1949) (citing Bi-Metallic Inv. Co. v. State Bd. of Equalization, 239 U.S. 441 (1915). But see Southern Ry. v. Virginia, 290 U.S. 190 (1933). However, they fail to deal with the non-representative nature of agencies. See text accompanying notes $28-33$, infra. See generally $1 \mathrm{~K}$. DAvis, supra note $9, \S 6.05$.

26. See generally K. DAVIS, supra note $9, \S \S 2.00-1,-2$ (Supp. 1970).

27. Provost v. Betit, 326 F. Supp. 920 (D. Vt. 1971) presents a clear example of confusion between substantive and procedural restraints on ruleinaking. The court held that no public participation was constitutionally required in the formulation of a rule which would substantially reduce welfare benefits. Its reasoning rested on the state's power to regulate the welfare system without second-guessing by courts. Id. at 924 . This rationale confuses judicial review of procedures with review of substance, and procedural due process with substantive due process. While Dandridge v. Williams, 397 U.S. 471 (1970), which the court cites in support of its holding, 326 F. Supp. at 924, held that the rational basis standard of review applies to welfare regulations, it does not imply that agencies may not be subject to procedural requireinents when formulating those regulations.

28. While this is true of agency staffs as a whole, appointments to the most powerful adininistrative positions are often made on the basis of political considerations. Lazarus \& Onek, The Regulators and the People, 57 VA. L. Rev. 1069, 1078 (1971). Political appointment decreases responsiveness of agencies to concerns of groups who are relatively powerless politically and economically. Nevertheless, it inay be generally stated that expertise is the backbone of the administrative system. The judicial attitude of deference to agency actions is premised on this expertise, $4 \mathrm{~K}$. DAvrs, supra note 9 , $\S 30.09$ (1958 and Supp. 1970), much as judicial deference to legislatures is premised on democratic representation. 
within regulated industries rather than by opposing industry interests. ${ }^{20}$ Moreover, the prospect of future einployment within regulated industries encourages administrators to give deference to imdustry interests, rather than vigorously searching out countervailing public considerations. $^{30}$ Thus, little effort is made to ensure a broad spectrum of viewpoints or backgrounds on agency staffs, and the selection process itself excludes persons with "anti-industry" interests, such as environmentalists $^{31}$ and consumer advocates, ${ }^{32}$ as well as representatives of certain

29. Coalescence of personnel on agency staffs and those intimately connected with the regulated industries has been described as the "subgovernment phenomenon"-"a coalescence of lobbyists, specialty lawyers, trade associations, trade press, congressional subcommittee staff-members, and commission personnel who cluster around each of the regulated industries." These people move from one organization to another within the subgovernment. However, "[t]hose who pursue the course of protecting the public interest are rarely admitted." Johnson, $A$ New Fidelity to the Regulatory Ideal, 59 Gro. L.J. 869, 883-84 (1971).

30. Johnson describes this prospect of future employment as the "deferred bribe." Id. at 885 .

31. The National Environmental Policy Act of 1969, 42 U.S.C. $\$ 4321$ et seq. (1970), attempts to counteract the lack of environmental imput in internal agency decisionmaking by requiring agencies to consider the environmental impact of all actions which they undertake and of all legislation which they recommend. Id. at $\S 4332$. The statute requires the agency to make a threshold determination whether projects are "major federal actions significantly affecting the quality of the human environment." If they are, the agency must obtain comments from any other federal agency "which has jurisdiction by law or special expertise with respect to any environmental impact involved" and then prepare an environmental impact statement. Id. Although the Act itself does not require opportunity for public notice and comment before the threshold determination is made or before the impact statement is prepared, $\S 2 b$ of Executive Order No. 11,514 requires federal agencies to develop procedures to provide timely information to the public and to hold public hearings "whenever appropriate" in order to obtain the views of interested parties on federal plans and programs with environmental impact. Exec. Order No. 11,514, 3 C.F.R. 271 (1974), 42 U.S.C. $\$ 4321$ (1970).

The inost crucial determination is the threshold decision as to whether the project is a major federal action with significant effect on the environment. If it is not, no environmental impact statement is necessary. Under the statute, this decision is left to the good faith judgment of the agency. Hanly v. Kleindienst, 471 F.2d 823, 830 (2d Cir. 1972). However, if public participation is not found "appropriate" at this stage, the agency biases in favor of the regulated industries may well result in reluctance to find significant environmental impact. In response to this problem, some courts have required agencies to prepare a reviewable record on the issue of whether an impact statement is necessary. Hanly v. Mitchell, 460 F.2d 640 (2d Cir.), cert. denied, 409 U.S. 990 (1972); cf. Scherr v. Volpe, 466 F.2d 1027 (7th Cir. 1972). In addition, other courts have required public input as part of this process. Hanly v. Kleindienst, 471 F.2d 823, 836 (2d Cir. 1972), cert. denied, 412 U.S. 908 (1973); Simmans v. Grant, 370 F. Supp. 5, 19 (S.D. Tex. 1974). But see San Francisco Tomorrow v. Romney, 342 F. Supp. 77 (N.D. Cal. 1972). See also EPA Reg., 40 C.F.R. $\$ 6.25$ (1974) (negative declaration and environmental impact appraisals).

32. For a discussion of almost fifty years of efforts to ensure representation of consumer interests before agencies and in the executive branch, see Leighton, Consumer Protection Agency Proposals: The Origin of the Species, 25 AD. L. Rev. 269 (1973). Such a concept was advocated as early as 1926, when the "People's Counsel" was established to represent Washington D.C. public utility consumers in judicial and administra- 
segments of society, particularly the poor. ${ }^{33}$ Failure to elicit public comment and representation exacerbates this phenomenon, resulting in regulation which emphasizes private rather than public welfare. ${ }^{34} \mathrm{It}$ is also significant that agencies generally are not subject to public scrutiny. Agency decisions often become known to the public only when the results become evident. ${ }^{35}$ This insulates agencies from both general public pressure and specific requests to be lieard. ${ }^{36}$ Finally, legislatures cannot supervise every administrative decision; they are confined to broad reviews at varying intervals. ${ }^{37}$ Thus, administrative

tive proceedings. Since that time, there have been two main proposals for consumer representation. One has been to establisli a cabinet level department to represent consumer interests; the other has been to establish an independent agency. In recent years, the concept of a non-regulatory agency with extensive procedural powers to represent consumers before courts and agencies has gained increasing popularity. For an account of the complicated legislative maneuvering and serious disagreements as to the extent of the powers which should be given to the agency that have prevented passage of such a bill, see Leighton, The Consumer Protection Agency Bill-Ghosts of Consumerists Past, Present and Future, 28 Food Drug CoSM. L.J. 21 (1973).

33. Cf. Bonfield, Representation for the Poor in Federal Rulemaking, $67 \mathrm{MrCH}$. L. Rev. 511 (1969) [hereinafter cited as Representation for the Poor].

34. In Moss v. C.A.B., 430 F.2d 891 (D.C. Cir. 1970), thirty-two Congresspersons challenged approval by the C.A.B. of a six percent increase in air fares without public participation. The Board set the rates in a series of ex parte meetings with the airlines and, in effect, cooperated with the airlines in making its determinations. In response to the Board's argument that a requirement to follow the statutory procedure for ratemaking would "hobble the administrative process," the court answered, "We emphatically reject any intimation by the Board that its responsibilities to the carriers are more important than its responsibilities to the public." Id. at 902. See also the statement by Lewis A. Engman, Chairman of the FTC, in which he attacked regulatory agencies for contributing to inflation by discouraging competition and protecting regulated industries. N.Y. Times, Oct. 8, 1974, at 1, col. 6 .

35. Subject to certain exceptions, the APA requires notice of proposed rulemaking to be published in the Federal Register. 5 U.S.C. $\& 553(\mathrm{~b})$ (1970). The resulting problem of lack of effective notice to the general public has been commented on extensively. See, e.g., Representation for the Poor, supra note 33, at 524; Johnson, supra note 29, at 880-81; Reich, The Law of the Planned Society, 75 YALE L.J. 1227, 1244 (1966). See also Administrative Conference of the UnIted States, Recommendation 28: Public Participation in Administrative Hearings, A(1), appended in Cramton, The Why, Where and How of Broadened Public Participation in the Administrative Process, 60 GEO. L.J. 525, 547-50 (1972). In contrast, in addition to publication in the California Administrative Register, the California APA requires notice to be published in an appropriate newspaper, and to be mailed to any person who has filed a request with the agency; it also allows the agency to mail notice to any person or group it beheves would be interested in the proposed rule. CAL. Gov'T CoDE $\$ 11423$ (West 1966).

36. See, e.g., Johnson, supra note 29 , at $873-74$, which cites the example of a proposed FCC rule to change the license renewal procedure by giving the public only sixty days, rather than ninety, in which to file petitions prior to renewal. Notice was published in the Federal Register. Comments were received from 166 stations, three networks, and a Washington law firm which had a large number of clients engaged in broadcasting; in contrast, only two public groups submitted coinnents, which consisted of a six page brief and a three-paragrapli letter.

37. See Jaffe, An Essay on Delegation of Legislative Power, 47 Colum. L. Rev. $359,372-74$ (1947). 
rulemaking lacks the guarantees against arbitrariness and control by powerful interests which are inherent in the size and political diversity of legislatures themselves and in the ponderous procedural checks and balances of the legislative process.

If the legislature set specific standards and the agency were merely a regulatory and implementative arm of the legislature, it might be argued that lack of representation of certain groups at the agency level would not warrant judicial intervention. Congress, however, cannot set detailed standards for agencies which deal with increasingly complex problems. Since the passage of the APA in 1946, the scope of activities and number of federal agencies alone have grown at a phenomenal rate. Their power and breadth of discretion have increased accordingly. Agencies no longer act solely as regulatory bodies, but also as mini-legislatures. They are empowered to make policy " $\mathrm{m}$ the public interest," a standard which the agency itself defines. ${ }^{88}$ Rulemaking by agencies heavily biased toward powerful economic and pohitical interests collides with the premise that all segments of society should have a voice in setting policies which will govern them in the future. ${ }^{39}$ A realistic appraisal of the allocation of power between the legislature and administrative agencies suggests that the unrepresentative nature of the agency process threatens this basic tenet of democratic pluralism.

These considerations have, in recent years, engendered increasing attacks on federal agencies. ${ }^{40}$ Because administrators have a commumity of interest with those they are supposed to regulate, and because outside interests are not otherwise represented in the administrative process, agencies lave been widely criticized as the handmaidens of the imdustries which they in theory control. ${ }^{41}$ Many commentators

38. See K. DAvIs, supra note 9, $\S 2.00-3$ (Supp. 1970); Reich, supra note 35, at 1233-40.

39. This philosophy underlies the rulemaking provisions of the APA:

Day by day Congress takes account of the interests and desires of the pcople in framing legislation, and there is no reason why administrative agencies should not do so when they exercise legislative functions which the Congrcss has delegated to them.

S. Doc. No. 248, 79th Cong., 2d Sess. 359 (1946). For a judicial statement emphasizing the need for public participation in rulemaking if a viable democratic system is to be maintained, see NLRB v. Wyinan-Gordon Co., 394 U.S. 759, 777-78 (1969) (Douglas, J., dissenting).

40. For a summary of recent criticisms, see Comment, Public Participation in Federal Administrative Proceedings, 120 U. PA. L. REv. 702, 707-09 (1972).

41. These problems do not occur only in agency regulation of industry. For an example of the same failure to regulate in the public interest in the case of HEW regulation of local urban renewal agencies, see Tondro, Urban Renewal Relocation: Problems in Enforcement of Conditions on Federal Grants to Local Agencies, 117 U. PA. L. REv. 183, 198-202. Tondro concludes that "the RAA [HUD], in its supervision of relocation, has becoine yet another regulatory agency now controlled by the very interests it 
have argued that representation of all groups significantly affected by agency decisionmaking may well be the means by which to make administrative bodies more responsive to the public as a whole. ${ }^{42}$

The traditional doctrine that procedural due process places no restriction on administrative rulemaking proceedings thus ignores the realities of the administrative process. The same individual interests which rigid procedural safeguards protect in the adjudicative setting may be at stake in agency rulemaking. ${ }^{43}$ Individuals should be able to argue that they have been deprived of procedural due process when policy decisions which substantially affect them are inade without representation of their views before the agency. ${ }^{44}$ Furthermore, although agencies may have expertise in a defined area of administration, affected but unrepresented parties may provide a useful point of view

was designed to regulate." Id. at 199 . He attributes this, at least in part, to the failure of HUD to allow resident participation in the federal decisionmaking process. Even though local agencies may be douninated by powerful local business interests with concerns diametrically opposed to those of the displaced residents, HUD depends on local urban renewal agencies both to develop standards to ensure adequate relocation of displaced residents and to provide the information showing whether the standards have been met.

42. "The cardinal fact that underlies the demand for broadened public participation is that governmental agencies rarely respond to interests that are not represented in their proceedings." Cramton, supra note 35, at 529; see Reich, supra note 35, at 1247. See generally Lazarus \& Onek, supra note 28.

Congress has also responded in some instances to the demand that the pnblic have a right to participate in decisionmaking which significantly affects the quahity of life. Expansion of the statutory right to a public hearing concerning proposed highway construction provides an example of increased congressional concern with agency responsiveness. In 1968, the Federal-Aid Highway Act was amended to require that opportunity for hearing be afforded by the state highway agency to consider "the economic and social effects of [the proposed] location, its impact on the environment, and its consistency with the goals and objectives of such urban planning as has been promulgated by the community." Act of Aug. 23, 1968, Pub. L. No. 90-495, $\$ 24,72$ Stat. 902, amending 23 U.S.C. $\$ 128$ (a) (1964) (codified at 23 U.S.C. $\$ 128(a)$ (1970)). In addition, the Federal Highway Act of 1970 requires the state agency to subnit a report indicating the consideration given to these factors and alternatives raised at the hearing or otherwise considered, as well as a transcript of the hearings. Act of Dec. 31, 1970, Pub. L. 91-605, Title I, $\$ 135,84$ Stat. 1734, amending 23 U.S.C. $\$ 128$ (1964) (codified at 23 U.S.C. $\$ 128($ b) (1971)). See generally D.C. Fed'n of Civic Ass'ns, Inc. v. Volpe, 434 F.2d 436, 440-41 (D.C. Cir. 1970), cert. denied, 405 U.S. 1030 (1971).

43. See note 24 supra.

44. One commentator has postulated the argument that, while an individual interest in government benefits such as public housing or welfare may be protected against erroneous factual evaluations, the same individual may have no constitutionally protected expectation that the state will not terninate the benefit by a change of policy. Note, Procedural Due Process in Government Subsidized Housing, supra note 5, at 897-98 n.89. This argument implies that the interest is qualitatively different in the legislative context, and may thus be said to be beyond the pale of due process guarantees. However, since only the nature of the proceeding is different and the individual's interest has not changed, this argument simply restates the proposition that procedural due process does not apply to rulemaking. 
or particular facts which would otherwise be ignored. ${ }^{45}$ Failure to consult all interested parties may therefore open an agency decision to attack on substantive due process grounds. ${ }^{46}$ Finally, the symbolic function of procedural due process-to ensure belief in the fairness of the governmental decisionmaking process-is particularly important in the context of rulemaking which substantially affects the lives of many people. ${ }^{47}$ Thus, to forestall the dangers of arbitrary decisionmaking caused by lack of representation of some interest groups in the internal administrative structure and in the rulemaking process as a whole, an affirmative right to participate nust be established.

\section{B. Nonconstitutional Rights of Participation}

While courts have clung to the traditional notion that due process imposes no restrictions on administrative rulemaking, they have not ignored the strains which this doctrine imposes on fundamental precepts of democratic pluralism. Pressures arising from the ever-increasing impact of rulemaking and from the growing recognition of the inability of agencies to represent the public interest as a whole have led courts to attempt to accommodate demands by affected groups to par-

45. Bonfield, Public Participation in Federal Rulemaking Relating to Public Property, Loans, Grants, Benefits, or Contracts, 118 U. PA. L. REv. 540, 540-41 (1970) [hereinafter cited as Public Participation].

46. Cf. Powelton Civic Home Owners Ass'n v. Dep't of Housing and Urban Dev., 284 F. Supp. 809, $831-32$ (1968); Provost v. Betit, 326 F. Supp. 920, 924 (D. Vt. 1971). In United States v. Carolene Products, 304 U.S. 144, 153 n.4 (1938), the Court expressly reserved decision on the question whether prejudice against discrete and insular minorities which inhibits legislative protection of their interests by excluding them from the political process would require the Court to strictly scrutinize laws affecting these groups. Later cases have settled the question in favor of strict scrutiny. See, e.g., Graham v. Richardson, 403 U.S. 365 (1971) (alienage); cf. Frontiero v. Richardson, 411 U.S. 677 (1973) (plurality opinion) (sex). The direct connection between representation and the judicial presumption that laws ineet substantive due process requirements, which the Court hinted at in Carolene Products, was recognized by the Court in Kramer v. Union Free School Dist., 395 U.S. 621, 628 (1969):

The presumption of constitutionality and the approval given "rational" classi-

fications in other types of enactments are based on an assumption that the institutions of state government are structured so as to represent fairly all the people. . . . Legislation which delegates decisionmaking to bodies elected by only a portion of those eligible to vote for the legislature can cause unfair representation. Such legislation can exclude a ininority of voters from any voice in the decisions just as effectively as if the decisions were made by legislators the minority had no voice in selecting.

While groups excluded from rulemaking processes may not always correspond to those minority groups designated "suspect categories," policy decisions by unrepresentative agencies which fail to consider the interests of these excluded groups should also be subject to strict scrutiny.

47. D.C. Fed'n of Civic Ass'ns, Inc. v. Volpe, 434 F.2d 436, $441-43$ (D.C. Cir. 1970), cert. denied, 405 U.S. 1030 (1972); Cramton, supra note 36, at 531; see note 5 supra. 
ticipate in the administrative process. By liberalizing the law of administrative intervention, courts have allowed both broadened representation in agency proceedings and inore effective review of agency decisionmaking.8 While this judicial development is ostensibly not of constitutional dimensions, it adumbrates recognition by the courts of a due process right to minimal participation in rulemaking. In effect, the courts have undermined the traditional refusal to recognize procedural rights in the rulemaking context. Eventually, this development Inay lead to explicit recognition of such rights.

Generally, the leading cases have concerned the right to imtervene in formal administrative proceedings. ${ }^{49}$ In Scenic Hudson Preservation Conference v. FPC, ${ }^{50}$ conservation groups sought review of the FPC's decision to grant a permit to build a hydroelectric plant. Plaintiffs asserted that the Commission had not adequately considered the

48. In Environmental Defense Fund, Inc. v. Ruckelshaus, 439 F.2d 584 (D.C. Cir. 1971), the Secretary of Agriculture refused to call public hearings required by statute once he found that there was substantial question as to the safety of DDT. He maintained that the matter was still under investigation. The court required him to initiate the administrative procedure to review the pesticide registration: "For when Congress creates a procedure that gives the public a role in deciding important questions of public policy, that procedure may not hightly be sidestepped by administrators." Id. at 594 . The court reasoned that the public hearings, aside from giving the inanufacturer a right to challenge a decision to cancel registration, "bring the public into the decision-making process, and create a record that facilitates judicial review." Id. at 595; accord, Moss v. CAB, 430 F.2d 891, 900 (D.C. Cir. 1970); see Coinment, supra note 40, at 710-12.

[W] ithout participation in the administrative learing, issues which appellants

here might wish to raise about the character of the state's plans may lave been

foreclosed as a topic for review. Moreover . . . limited review underscores the need for appellants' participation in the administrative hearings as a party.

Nat'l Welfare Riglits Org. v. Finch, 429 F.2d 725, 737 (D.C. Cir. 1970); accord, American Communications Ass'n v. United States, 298 F.2d 648 (2d Cir. 1962); First Nat'l Bank v. Saxon, 352 F.2d 267, 273 (4th Cir. 1965) (Sobeloff, C.J., dissenting).

Public participation not only facilitates judicial review by creating a record which brings all relevant considerations to the courts' attention, but also safeguards the right to review by allowing the party to bring in its arguments for consideration at a preliminary stage. This is especially important if the scope of review is limited to a determination of whether the agency decision is arbitrary or capricious.

49. Insofar as these cases concern licensing proceedings, under the APA they are technically adjudicative. See 5 U.S.C. $\$ \S 551(6)-(7)$ (1970). Section $6($ a) of the APA permits intervention in adjudicative proceedings according to the discretion of the agency. "So far as the orderly conduct of business permits, an interested person may appear before an agency or its responsible employees for the presentation ... of an issue, request, or controversy in a proceeding . . . or in connection with an agency function." Id. $\S 555(\mathrm{~b})$. However, these proceedings demonstrate the difficulty of drawing a clear line between rulemaking and adjudication. In a complicated licensing proceeding such as that in which an agency decides whether to permit construction of a hydroelectric plant or to renew a radio license, the interests of the public are intiniately involved. Presumably, the agency exercises a planning function; its decision should be "designed to implement, interpret, or prescribe law or policy." Id. \$551(4) (definition of "rule").

50. 354 F.2d 608 (2d Cir. 1965), cert. denied, Consolidated Edison Co. v. Scenic Hudson Preservation Conf.. 384 U.S. 941 (1966). 
environmental factors or given enough study to less harmful alternatives. The court agreed with these claims. In response to the argument that plaintiffs had no standing to seek review, the court held that "the Federal Power Act gives petitioners a legal right to protect their special interests." The court specifically included the right to intervene in subsequent proceedings "in order to insure that the FPC will adequately protect the public interest" ${ }^{\prime 2}$ and fulfill its statutory planning function. Office of Communication of United Church of Christ v. FCC,,$^{53}$ which relied heavily on Scenic Hudson, developed the right of intervention more fully. Plaintiffs did not request review of the agency's decision, but rather demanded remand to the agency so that they could participate in the licensing procedure. ${ }^{54}$ The court held that, in order to comply with its statutory planning function, the FCC was required to allow plaintiffs to intervene as representatives of the public interest. In response to the Commission's claim that it was, by designation of Congress, the representative of the public interest, the court stated:

The theory that the Commission can always effectively represent the listener interests in a renewal proceeding . . . is one of those assumptions we collectively try to work with so long as they are reasonably adequate. When it becomes clear, as it does to us now, that it is no longer a valid assumption which stands up under the realities of actual experience, neither we nor the Commission can continue to rely on it. ${ }^{55}$

51. Id. at 616.

52. Id. at 616-17.

53. 359 F.2d 994 (D.C. Cir. 1966).

54. In United Church of Christ, the FCC renewed a radio station's license through an informal procedure, since it claimed that there were no issues of fact. The court held that the agency had to hold a hearing. The plaintiffs' right to assert the pubhic interest could not be foreclosed by avoiding procedures which gave the public access to the Commission.

55. 359 F.2d at 1003-04; cf. Scenic Hudson Preservation Conf. v. FPC, 354 F.2d 608, 620-21 (2d Cir. 1965).

In both of these cases, the fact that plaintiffs had standing to seek review gave the courts an additional reason to require intervention. In United Church of Christ, the court explicitly employed the standard used to determine whether a party has standing to seek judicial review in order to find a right to intervene. The court reasoned that the use of such a broad standard would not result in overwhelming the Commission, since it could regulate the extent of participation to be permitted and, in addition, could determine by creating appropriate standards which representatives would be allowed to intervene. 359 F.2d at 1005-06; accord, Scenic Hudson Preservation Conf. v. FPC, 354 F.2d 608, 617 (2d Cir. 1965); Palisades Citizens Ass'n v. CAB, 420 F.2d 188 (D.C. Cir. 1969).

In a subsequent case involving the Office of Communication of the Umited Church of Christ, the court held that, in order to ensure the effectiveness of the right to intervene, the FCC had to allow reimbursement of expenses to the plaintiff where provided for in its rules. Office of Communications of United Church of Christ v. FCC, 465 F.2d 519 (D.C. Cir. 1972). 
The reasoning of these two leading cases directly refutes the foundation for the refusal to recognize due process restrictions on administrative rulemaking. These courts rejected the idea that an agency can, like a legislature, represent the "public interest" without actually consulting various interested segments of the public. Administrative or technical expertise, the courts realized, does not guarantee consideration of all points of view. Recognition of the unrepresentative nature of agencies makes manifest the need for procedural protections against substantive arbitrariness. While these courts depended on statutory interpretation in order to find a right to intervene, ${ }^{56}$ the underlying issue is procedural and substantive fairness. ${ }^{57}$

\section{III}

Rulemaking Under the Federal Administrative Procedure Act: THE 553(a)(2) EXCEPTION

The expansion of administrative power and discretion through rulemaking has led to recent emphasis on the importance of broad pubhic participation in administrative proceedings. ${ }^{58}$ However, recognition of the need for participation is not a new concept; it is reflected in the basic rulemaking provisions of the APA as passed in 1946.59 Cognizant of the need to provide a minimal right of representation, Congress required agencies to give interested persons notice and opportunity to submit written comments when proposing to enact a rule. ${ }^{80}$ The legis-

56. See also Nat'l Welfare Rights Org. v. Finch, 429 F.2d 725 (D.C. Cir. 1970). The court held that a group of welfare recipients had the right to intervene in au HEW conformity hearing to determine whether federal welfare funds should be cut off for the state's failure to follow federal requirements. The court specifically did not reach the due process argumeut. Id. at 734 n.33.

57. "The spirit of these cases is that procedural fairness requires an effective opportunity to be heard prior to governmental interference with financial interests which go to the core of sustenance." Comment, Intervention in HEW Welfare Conformity Proceedings, 6 Harv. Civ. Rights-Civ. LIB. L. Rev. 559, 570 (1971). This Comment advocates a balancing test for intervention such as that used by the Supreme Court in Goldberg v. Kelly. See note 13 supra and accompanying text. This functional approach, which clearly reflects a procedural due process orientation, is thoroughly expounded in Shapiro, Some Thoughts on Intervention Before Courts, Agencies, and Arbitrators, 81 HARV. L. REv. 721 (1968).

58. See part I supra.

59. 5 U.S.C. \& 553 (1970) (origiually enacted as Act of June 11, 1946, ch. 324, $\S 4,60$ Stat. 238).

60. Id. $\S 553(\mathrm{c})$. This section also requires the agency to incorporate in the rule a brief statement of its basis and purpose. Unless it comes within several exceptions, the rule must be published not less than thirty days before it becomes effective. Id. $\S$ $553(\mathrm{~d})$.

This comment deals only with participation in rulemaking proceedings governed by the notice and written comment procedure of Section 553. Some agencies are required by statute to make rules using formal adjudicative procedures. See note 10 supra. Where such a requirement applies, special problems create additional hurdles to public 
lative history clearly demonstrates that the requirement of public participation was motivated by the realization that important private interests may be affected by agencies which are neither representative of, nor informed about all points of view. ${ }^{61}$ The statutory rulemaking requirements represent the outcome of a balancing procedure similar to that developed by the courts in procedural due process cases. ${ }^{22}$ The need for affected members of the public to have an opportunity to protect their interests and the need for agencies to be apprised of all viewpoints in order to adequately exercise their delegated power to act in the public interest were balanced against the requirements for flexibility and efficiency in the rulemaking process. The legislative scheme makes notice and comment the norm which provides the basic protections essential to informed, democratic rulemaking. Departures from this norm, either to permit additional participation or none at all, are generally allowable only on a case by case basis in light of particular circumstances. $^{63}$ However, Congress also established a blanket exception to the notice and comment requirements. In section 553(a)(2), the APA excepts all rulemaking concerning rules "relating to public property, loans, grants, benefits, or contracts." ${ }^{44}$ In this extremely broad area, the APA allows participation only at the agency's discretion. ${ }^{65}$

participation. See generally Cramton, supra note 35; Gellhorn, Public Participation in Administrative Proceedings, 81 YALE L.J. 359 (1972); Comment, supra note 40.

61. "Public participation] in the rulemaking process is essential in order to permit administrative agencies to inform theinselves and to afford adequate safeguards to

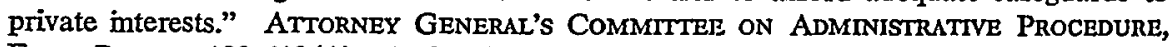
FnAal RePort 103 (1941), cited in S. Doc. No. 248, supra note 39, at 19-20, as justifification for enacting section 4 (the rulemaking provisions) of the APA. See Public Participation, supra note 45 , at $540-42$.

62. See text accompanying note 13 supra.

63. Agencies have the discretion to allow for oral presentation of arguments. 5 U.S.C. $\& 553(\mathrm{c})$ (1970). Conversely, in those instances where participation even by means of submission of written comments would so hamper the administrative process as to destroy the benefits inherent in the delegation of rulemaking authority, the agency is permitted to proceed without notice and comment. Under section $553(\mathrm{~b})(\mathrm{A})$, participation is not required in the case of interpretative rules, general stateinents of policy, or rules governing internal agency organization, procedure or practice. In addition, under $553(\mathrm{~b})(B)$ the agency may make a finding that participation is impracticable, unnecessary, or contrary to the public interest; it must publish the reasons for this finding in the rule when it is issued.

64. Significantly, The Model State Administrative Procedure Act drafted by the Uniform Law Commissioners omits the exception, as does the CALIFORNIA ADMINIStrative Procedure ACT, CAL. Gov'T CODE $§ \S 11370-528$ (West 1966).

65. For a discussion of the legislative history of the 553(a)(2) exceptions and their significance, see Public Participation, supra note 45. In that article, Professor Bonfield concludes that the exemptions have an enormous impact:

[The exemptions] are extraordinarily broad and of very great significance. They [exclude] an enormous quantity of rulemaking from the requirements of section 553. . . The rulemaking involved has a great impact on our national effort to cure the pressing human problems of the last half of the tweutieth 


\section{A. Justification}

Several rationales have been advanced to explain the 553(a)(2) exception. ${ }^{66}$ It has been explained on the grounds that public property, loans, grants, benefits and contracts involve "privileges" rather than "riglits," thus obviating the need for participation by those who are to receive such bounties. ${ }^{67}$ However, the right-privilege distinction can no longer be rehed upon as a valid explanation for such an important denial of procedural protections. ${ }^{68}$ Moreover, the distinction does not explain the policy reasons which require the right of participation granted generally in section 553 to be abrogated. ${ }^{69}$ The same criticism applies to the argument strongly advanced by the floor manager of the APA in the House, namely, that in its "proprietary" functions, the government, like the ordinary busniess person or entrepreneur, should not be required to allow public participation in decisionmaking. ${ }^{76}$

It has also been argued that the 553(a)(2) exception serves to protect the efficiency of the governmental process. ${ }^{71}$ This argument, however, may equally be advanced as to the rulemaking provisions as a whole. ${ }^{72}$ Congress concluded in establishing a right to participate

century. . . . Efforts to solve our urban crisis, racial problems, poverty problems, environmental quality difficulties, and human spirit and character maladjustments have been mainly pursued through the use of "public property, loans, grants, benefits, or contracts."

Id. at 570. See also Housing Authority v. United States, 468 F.2d 1 (8th Cir.), cert. denied, 410 U.S. 927 (1972). It should be noted that the statute creates a classification which places a special burden on the poor, who are greatly affected by rulemaking in these areas. See generally Representation for the Poor, supra note 33.

66. For a complete discussion and critique of these rationales, as advanced by various agencies which have opposed elimination of the exception, see Public Participation, supra note 45 , at $571-83$.

67. Id. Alternatively, it has been argued that those who elect to receive such benefits are not obligated to deal with the government and are therefore bound to accept the terms on which the government wishes to deal. Id. at 571-72.

68. Van Alstyne, supra note 20; Goldberg v. Kelly, 397 U.S. 254, 261-63 (1970); see text accompanying note 20 supra.

69. Public Participation, supra note 45, at 573-74. See generally Van Alstyne, supra note 20.

70. S. Doc. No. 248, supra note 39, at 358; Public Participation, supra note 45 , at 572-73. This argument is subject to the further criticisn that "proprietary" functions of government are difficult to identify. The label therefore fails to provide a meaningful standard.

71. [T] The exception of proprietary matters is included because the principle considerations in most such cases relate to mechanics and interpretations of policy, and it is deemed wise to encourage and facilitate the issuance of rules in these areas by dispensing with all mandatory requirements.

S. Doc. No. 248, supra note 39, at 199, 247. See Public Participation, supra note 45, at $575-78$.

72. Professor Bonfield persuasively argues that there is no need for such an exception to protect the efficiency of the rulemaking process in these areas; agencies may avoid notice and comment when they are unnecessary or not in the public interest on 
that the need for informed decisionmaking and protection of individual rights outweighed considerations of efficiency. The nature of the procedure itself was the means by which efficiency could be safeguarded. Since the nature of the rulemaking in the excepted areas does not differ from rulemaking in other areas, this justification for the 553(a)(2) exception is weak at best.

Thus, no cogent reason has been advanced to explain why participation in the excepted areas would be such a burden as to require a blanket exception to the notice and comment requirements. ${ }^{73}$ Indeed, because these areas affect such vital individual and national interests, the need for public participation is particularly acute. In view of the quantity and nature of rulemaking covered, the statutory exception raises a pressing need for judicial recognition of a due process right to participate in rulemaking.

\section{B. Application}

Even if its underlying rationale were theoretically acceptable, the 553(a)(2) exception presents difficult problems of practical application. An individual whose interests are affected by rulemaking within the excepted area has no procedural rights. However, if the proceeding is labelled adjudicative, due process requires that the same individual be accorded significant procedural protections. ${ }^{74}$ The deternination whether a proceeding is rulemaking or adjudication thus acquires significance of constitutional dimensions. Yet, the distinction is far from clear..$^{75}$

The problem may be approached in two ways. First, one can say that the agency engages in rulemaking when it acts like a legislature and promulgates rules, and it engages in adjudication when it acts like a court and issues orders. ${ }^{76}$ However, this approach, which depends

a case by case basis under section 553(b)(B). Public Participation, supra note 45 , at 598-608.

73. It might possibly be argued that the 553(a)(2) exemption violates equal protection on the grounds that it lacks a rational basis. If it could be shown, however, that the exempted categories account for a portion of rulemaking greatly in excess of all others, the exception might be justified as rational. Cf. Rodriguez v. Swank, 318 F. Supp. 289, 296 (N.D. III. 1970), aff'd mem., 403 U.S. 901 (1971) (rational interest in assuring flexibility and expeditious administration of grants-in-aid). This is particularly true in light of the degree of deference the court has shown in utilizing the rational basis standard. See McGowan v. Maryland, 336 U.S. 420 (1961). The exemption is particularly vulnerable to attack, however, if participation is seen as a fundamental right analogous to the right to vote. This would subject the exception to strict judicial scrutiny. See the discussion of Federation of Civil Ass'ns v. Volpe, 434 F.2d 436 (D.C. Cir. 1970), in part III infra.

74. See text accompanying notes 11-24 supra.

75. See generally Robinson, supra note 9.

76. This is the approach of the APA. Before it can be determined which pro- 
upon an unclear definitional distinction, is often unsatisfactory. Many agency proceedings, such as ratemaking, are neither clearly legislative nor clearly adjudicative. ${ }^{77}$ The agency should not be able to condition important procedural rights on a label. ${ }^{78}$ Further, the courts have manipulated this vague distinction to avoid ruling on the constitutionality of the 553(a) (2) exception. In two recent federal district court decisions, Geneva Towers Tenants Organization v. Federated Mortgage Investors ${ }^{79}$ and Keller v. Kate Maremount Foundation, ${ }^{80}$ both unpublished, plaintiffs raised the claim that HUD approval of a rent raise in publicly subsidized housing without affording notice and a full hearing to the tenants was a violation of due process. ${ }^{81}$ Using a balancing

cedure must be followed, one must first decide whether the agency is engaging in rulemaking or adjudication. The crucial definition is contained in 5 U.S.C. $\$ 551(4)$ (1970) - a rule is defined as "the whole or part of any agency statement of general or particular applicability and future effect designed to inplement, interpret, or prescribe law or policy . . . While most cases will clearly fall withm or without this definition, the addition of the words "or particular" in this definition causes confusion, especially since licensing would seem to come within their scope, yet is specifically defined as adjudication. See 5 U.S.C. $\$ 551(6)$ (1970). The Model State APA avoids this problem by defining a rule as "each agency statement of general applicability that iniplements, imterprets, or prescribes law or policy ...." MODEL STATE APA, \& 1(7) (1970).

77. See, e.g., Morgan v. United States, 298 U.S. 468, 480 (1936), where the Court reversed a long line of authority lolding ratemaking to be legislative, and labelled it "quasi-judicial." But cf. United States v. Florida E. Coast Ry. Co., 410 U.S. 224 (1973). American Air Limes, Inc. v. CAB, 359 F.2d 624 (D.C. Cir. 1966), provides an excellent example of the difficulties in drawing the line between the two categories. Although the $\mathrm{CAB}$ modified existing licenses of only five carriers by issuing a rule that only all-cargo carriers could provide "blocked space" service, the court upheld this procedure. The court found that existing rights could be modified by rule so long as the proceeding was not "imdividual in impact and condemnatory in purpose" or based on a sham classification. Id. at 631. See also United States v. Storer Broadcasting Co., 351 U.S. 192 (1956); Airline Pilots Ass'n Int'l v. Quesada, 276 F.2d 892 (2d Cir. 1960).

It should be emphasized that these cases deal only with a problem of statutory interpretation. In each case the parties participated in the rulemaking proceedimgs, but argued that adjudicative proceedings were required when rulentaking proceedings had the effect of modifying their licenses. In such a situation the rulemaking-adjudication distinction only determines what type of participation is to be allowed, not whether all procedural rights may be denied. Therefore, even if constitutional problems are raised by limiting participation, see part IV infra, the implications of reliance on the distinction are less drastic than those raised in the 553 (a) (2) context.

78. Citing the importance of participation as a safeguard against agency arbitrariness, courts have prevented agencies from avoiding rulemaking requirements by labelling the rules "interpretative" or "general statements of policy" in order to take advantage of the exemption of these types of rules from the requirenients of section 553. See 5 U.S.C. $\$ 553$ (b) (A) (1970). When the rule has a "substantial impact" on parties affected by it these courts have ordered compliance with the rulemaking procedures of the APA. See, e.g., Texaco v. FPC, 412 F.2d 740 (3d Cir. 1969); Pharmaceutical Mfrs. Ass'n v. Finch, 307 F. Supp. 858 (D. Del. 1970).

79. Civil No. C-70-104 SAW (N.D. Cal., Jan. 8, 1972).

80. Civil No. C-71-1585 RFP (N.D. Cal., June 15, 1972).

81. The decision to allow the raise was made after submission of a request with 
analysis, both courts determined that due process entitled the tenants to notice of the proposed rent increase and an opportunity to submit written comments. ${ }^{82}$ However, by labeling the decision to allow the raise "adjudicative," tutionality of the 553(a)(2) exception, which would have excused HUD from any requirement that it permit tenant participation.

The second approach to applying the rulemaking-adjudication distinction is also problematical. It assumes procedures to be neither wholly adjudicative nor wholly legislative. Rather, in any one proceeding issues of either type may arise. Thus, the second approach centers on the types of facts at issue. If they are "facts pertaining to the parties and their businesses and activities," they nuust be ascertained by applying procedural safeguards and allowing full party participation. On the other hand, if they are "general facts which help the tribunal decide questions of law and policy and discretion," then under traditional

accompanying data by the landlord to HUD. Id., slip opinion at 2 .

82. The courts held that the tenants lad an interest protected by due process, since a rent increase could well result in eviction for those families who could not afford it. Id. at 6-7; Geneva Towers Tenants Org. v. Federated Mortgage Investors, Civil No. C70-104 SAW (N.D. Cal., Jan. 8, 1972), slip opinion at 5. However, the courts also found that a requirement of a full hearing might well deter private investment in such projects and was not necessary to adequately protect the tenants' interests. Keller v. Kate Maremount Foundation, Civil No. C-71-1585 FRP (N.D. Cal., June 15, 1972), slip opinion at 9-10; Geneva Towers supra at 5.

83. Keller, Civil No. C-71-1585 FRP (N.D. Cal., Jan. 15, 1972), slip opinion at 7, citing Langevin v. Chenango Court, Inc., 447 F.2d 304 (2d Cir. 1971). Contra, Hahn v. Gottlieb, 430 F.2d 1243 (1st Cir. 1970). In Geneva Towers, the court, while noting the 553(a)(2) exception, did not decide whether the decision to permit a rent increase was legislative or adjudicative. Civil No. C-70-104 SAW (N.D. Cal., Jan. 8, 1972), slip opinion at 4-5 and n.1. It thereby avoided the constitutional problem. See also Powelton Civic Homeowners Ass'n v. HUD, 284 F. Supp. 809 (E.D. Pa. 1968), discussed at notes $88-95$ infra.

The conclusion that such a decision is adjudicative is of doubtful validity. While ostensibly it is made at the behest of the landlords and is one of "particular effect," in reality it is a decision whether to permit a rent raise which will affect all the tenants equally. It is "an agency statenient of general . . applicability and future effect," 5 U.S.C. $\$ 551(4)$ (1970), which depends in large part on broad economic determinations and policy considerations as to the proper return on the private investment rather than facts within the peculiar knowledge of the parties. Increased costs of management and similar facts needed to make the decision may be slown by submission of the proper documents. Of course, tenants may want to raise more limited issues in the proceeding such as the adequacy of services and upkeep; such questions may also be properly subject to documentary proof.

The objection may well be made that low-income tenants cannot adequately present their views in writing. Further, especially as to "adjudicative" issues such as quality of management, one can argue that tenants should be able to present witnesses and crossexamine. The real issue, therefore, which the court in Keller avoided by labelling the decision adjudicative, is whether due process may require more than notice and opportunity to submit written comment in a rulemaking proceeding. This issue is discussed in part IV infra. 
analysis all requirements of participation may constitutionally be ignored. $^{84}$ While such a formulation allows more flexibility in deciding which procedure to follow, the distinction between legislative and adjudicative facts also leads to confusion. Much depends on what issues are considered relevant to the question at hand..$^{85}$ Furthermore, any legislative fact may be broken down into narrow questions that present issues of adjudicative fact. ${ }^{86}$ The difficulty in distinguishing legislative and adjudicative facts has led at least one court to reject the distinction as unworkable. ${ }^{87}$

\section{III}

\section{Nascent Recognition of a Constitutional Right to Participate}

Courts have only recently begun to frame the issue of nonparticipatory rulemaking in terms of a due process analysis. While no court has directly challenged the constitutionality of the 553(a)(2) exception by finding a due process right to participate in rulemaking, the implication of these decisions is that such a constitutional right exists.

Recoguition of this due process right may take two forms. Some courts have realized that the right of participation in decisions affecting vital interests cannot be premised solely on whether general policy is to be made or specific facts are to be found. Without further analysis, these courts have proceeded to find minimal participation rights. In contrast, at least one court has based its analysis on the unrepresentative nature of the agency process by analogizing participation in rulemaking to the right to vote.

\section{A. The Legislative-Adjudicative Distinction: A New Approach}

In Powelton Civic Homeowners Association v. HUD, ${ }^{88}$ the court

84. The distinction between legislative and adjudicative facts was formulated by Professor Davis, and has been widely adopted by the courts. See $1 \mathrm{~K}$. Davis, supra note 9, §§ 7.01-02 (1958 and Supp. 1970).

85. For example, the court in Hahn v. Gottlieb, 430 F.2d 1243 (1st Cir. 1970), characterized the issues involved in FHA approval of a rent raise in a subsidized housing project as legislative: the relevant issues were considered to be "the landlord's financial condition, the intricacies of project management, and the state of the economy in the surrounding area;" facts about construction defects and maintenance and living conditions were thought to be irrelevant to the proceeding. $I d$. at 1248 . In contrast, the court in Langevin v. Chenango Court, Inc., 447 F.2d 296 (2d Cir. 1971), characterized the issues as adjudicative, although the dissent indicates that failure to provide proper maintenance was considered relevant. $I d$. at 300 .

86. See Robinson, supra note 9, at 503-04.

87. Yee-Litt v. Richardson, 353 F. Supp. 996, 1000 (N.D. Cal. 1973) (fact-policy distinction not viable in welfare context as basis of aid termination pending hearing); cf. Mothers' and Children's Rights Org. v. Sterrett, 467 F.2d 797 (7th Cir. 1972) (adequate opportunity for argument required even where termination of benefits rests only on question of law or policy).

88. 284 F. Supp. 809 (E.D. Pa. 1968). 
ignored the policy-fact dichotomy in awarding notice and comment rights. Plaintiffs, residents of an urban renewal area, attacked HUD approval of federal funding for a local redevelopment project. ${ }^{80}$ Alleging that the Secretary liad violated his statutory duty to consider whether a sufficient number of relocation units were available, they asked that the court require HUD to give them a full evidentiary hearing. The court refused this remedy; instead it ordered HUD to give plaintiffs an opportunity-equal to that given to the local redevelopment agency-to submit written and documentary evidence. It reasoned that HUD had a statutory responsibility to protect both the plaintiffs' private interests in adequate relocation facilities and the public interest in providing a decent home for every family. ${ }^{00}$ To fulfill these responsibilities, and to ensure that his decision would not be arbitrary, the court determined that the Secretary had a duty to expose himself to viewpoimts other than that of the local agency. ${ }^{01}$

The court had some difficulty, however, determining the proper remedy. It refused to require a full evidentiary hearing because the issues were questions of "legislative fact" to be taken into account in a broad planning decision. ${ }^{02}$ Moreover, the burden on HUD would be so great as to make participation unfeasible if a full hearing were

89. The plan was approved in informal proceedings; the state simply submitted its urban renewal plan to HUD for review. Id. at 818-19.

90. The court specifically declined to follow decisions refusing standing to plaintiffs adversely affected by the failure to plan for adequate relocation. The court found that plaintiffs had standing on the basis of their own economic injury and the statutory intent to protect their interests. Relying on Scenic Hudson Preservation Conf. v. FPC, 354 F.2d 608 (2d Cir. 1965), cert. denied, Consolidated Edison Co. v. Scenic Hudson Preservation Conf., 384 U.S. 941 (1966), the court held in addition that they had standing as appropriate parties to represent the public interest, since no one other than displaced residents would be sufficiently concerned to raise the public issues. $284 \mathrm{~F}$. Supp. at $820-28$.

91. "[W] do believe that the Seeretary must base his decisions on a complete record expressing the views of all recognized interests if he is to fulfill his planning function under the Housing Act." 284 F. Supp. at 832. The court carefully noted, however, that it did not decide the substantive correctness of the Secretary's decision. Id. at 816, 820 .

92. But cf. Shannon v. HUD, 436 F.2d 809 (3d Cir. 1970), where the court, in a similar situation, refused to allow plaintiffs to present evidence to HUD. The court there attempted to distinguish Powelton by arguing that the issue before the Shannon court-proper consideration of racial concentration in an urban renewal decision-required a "quasi-legislative" determination by HUD. It implied that, because the rights of the relocatees in Powelton were specifically protected by a requirement for adequate relocation procedures, the Secretary's decision there did not involve a "quasi-legislative" determination. The court in Shannon found that public participation was unnecessary: HUD, "with its own expertise," could supply the relevant data to make its decision. The court, however, then proceeded to list eleven factors which the agency must consider, while specifically disclaiming any intent to "limit the agency in the exercise of its own administrative expertise." Id. at 821-22. 
required. ${ }^{03}$ Thus, the court ruled, a formal hearing would be unnecessary. The alternative of informal participation by written comment brought the court face to face with the 553(a)(2) exception to the APA's rulemaking provision. To avoid this problem, it first noted that plaintiffs demanded an oral hearing, while section 553 only gave opportunity for notice and written comment. By implication, therefore, section 553 did not apply. The court then ingenuously proceeded to give plaintiffs exactly what the APA would have given them were it not for the exception: "However, the demands of due process do imply that the plaintiffs should be afforded an appropriate procedural opportunity to present their claims to the Secretary." ${ }^{4}$ This reasoning can be explained only by a desire to avoid finding section 553(a)(2) unconstitutional. In addition, although the court vacillated between basing the right to notice and comment on an implicit statutory requirement and basing it on an implicit constitutional requirement, the implicit requirement of participation the court found in the statute clearly was based on basic due process concepts of fair procedure and non-arbitrary decisionmaking:

Nowhere does the Housing Act explicitly require the Secretary to consider the views or claims of anyone other than the local public agency; nor does the Housing Act require the local agency to include any viewpoint or contentions other than its own in the inaterials submitted to the Secretary. Yet it is beyond argument that if the Secretary is statutorily obliged to inake decisions on the project's compliance with federal prerequisites, then he is implicitly obliged by due process to inake fair, non-arbitrary decisions. ${ }^{95}$

Two other courts lave found a right to participate by refusing to accord significance to the question of whether the proceeding involved rulemaking or adjudication in determining if procedural due process was applicable. In Appalachian Power Co. v. EPA, ${ }^{96}$ the court confronted a statute which, like section 553(a)(2), excepted the decisionmaker from notice and hearing requirements. Plaintiffs, steel manufacturers and operators of electric generating plants, sought review of the EPA Administrator's approval of a state plan implementing federal air

93. 284 F. Supp. at 829-30. The court engaged in a Goldberg type of balancing process to reach its decision that plaintiffs had no right to an evidentiary hearing:

However, it is the nature of the decision's fact-finding process, not the ultimate effect of the decision, that determines the right to an adjudicatory hearing. The statute here is silent; the essential facts to be found are "legislative"; the burden on the Secretary would be enormous; and the utility of an adjudicatory hearing is dubious.

Id. at 830 .

94. Id. at 830-31.

95. Id. at 831 .

96. 477 F.2d 495 (4th Cir. 1973). 
quality standards. They asked for remand to the agency, with instructions to provide an evidentiary hearing. The court specifically refused to characterize the Administrator's decision as rulemaking or adjudication. Rather, it examined the nature of the issues involved to determine what procedural requirements would apply. ${ }^{97}$ In drafting the Clean Air Act, the court concluded, Congress had specifically determined that, because the agency would be dealing with urgent considerations of health and public welfare, no hearing or participation requirement should be imposed.98 In thus interpreting the Act, the court noted that at the state level plaintiffs were given "full opportunity to present their contentions with respect to the proposed plan." ${ }^{.09}$ On a balancing of public and private interests, the court held that this procedure would conform with due process, "[a]ssuming that the state hearings were adequate and that the Administrator, in the course of his own evaluation of the state plans, reviewed those state hearings . . .."100 In effect, this holding required the Administrator to allow notice and comment participation even though the statute, as interpreted by the court, specifically excepted him from any obligation to do so: the plaintiffs could submit their arguments and data to him in written form through the transcripts of the state liearings. ${ }^{10 x}$

In Burr v. New Rochelle Municipal Housing Authority, ${ }^{102}$ the court used a similar analysis to find a due process right to participate. As the case involved no federal agency, the court, as in Appalachian, did not have to deal with section 553(a)(2). The district court held

97. Id. at 500-01. The court did, however, note that the agency itself characterized the proceeding as rulemaking. Id. at 500 . This would be correct, given the APA definition. Cf. Buckeye Power, Inc. v. EPA, 481 F.2d 162 (6th Cir. 1973).

98. 477 F.2d at 502-03. Contra, Buckeye Power, Inc. v. EPA, 481 F.2d 162 (6th Cir. 1973). In that case, the court held that, in spite of the state hearings, the administrator was subject to the rulemaking requirements of the APA. However, the court reasoned that since it would be impossible adequately to present highly technological data through written comments, the plaintiff could raise claims of technological impossibility of compliance as a defense in a federal or state enforcement proceeding. This solution of the participation problem clearly undermines the efficacy of federal clean air standards, and seems unsatisfactory with the solution reached in Appalachian.

99. $477 \mathrm{~F} .2 \mathrm{~d}$ at 503.

100. Id. at 504 (emphasis in original).

101. The court, without regard to the legislative-adjudicative distinction, used a due process balancing test to determine what procedures would be adequate. In this case, "[b]ecause of the drastic nature of the regulations and their drastic impact, such opportunity might well mclude the right to more than merely the opportunity to comment." Id. at 503. If presentation and cross-examination of witnesses were required, the notice and comment analogy would not be exact. Such procedures might serve to clarify the data or give it a different emphasis. The record submitted to the Secretary might be quite different than the written information and arguments ordinarily submitted in notice and comment proceedings.

102. 347 F. Supp. 1202 (S.D.N.Y. 1972), modified, 479 F.2d 1165 (2d Cir. 1973). 
that an evidentiary hearing was needed to comply with due process before rents in a municipal housing project could be imcreased. ${ }^{103}$ It reached this decision by balancing the tenants' significant interest in low rents and the relevance of their viewpoint to the issues against the minimal burden on the Housing Authority of holding a single hearing. ${ }^{104}$ The court of appeals, finding that the facts involved were "legislative," ${ }^{105}$ modified the lower court's holding so as to require only notice, opportunity to submit written comment, and a statement of reasons for the administrative decision. This decision applied the due process reasoning of the district court, which was predicated on the assumption that the issues were adjudicative, ${ }^{106}$ to a policy decision involving legislative facts. This characterization of the nature of the facts at issue, however, affected only the type of procedure required by due process; as in Powelton, it did not determine whether plaintiffs had any procedural rights.

The balancing approach used in these cases allowed the courts to account for the statutory scheme and to preserve the efficiency of the administrative process, while also protecting individual rights by assuring neaningful participation and adequate consideration of the participants' views. By refusing to accord imitial significance to the determination whether the decision was adjudication or rulenraking, the courts in Appalachian and Burr avoided the pitfall of relying on a distinction whicli cannot readily be defined, which is subject to agency nuaripulation, and which, when imvoked, may entirely foreclose the public from participation in agency decisioninaking. ${ }^{107}$

103. The district court relied on Langevin v. Chenango Court, Inc., 447 F.2d 296 (2d Cir. 1971). In that case, Judge Friendly found that there was no statutory right under the APA to a formal hearing. Characterizing the facts involved as "adjudicative," he reasoned that due process would ordinarily require a hearing. However, he found that there was no state action, since the housing, although federally subsidized, was privately run. Even assuming that the facts were legislative, he noted that section 553(a) (2) exempted the agency from notice and hearing requirements. Langevin also held that the agency's decision was not reviewable. Citing, anong other factors, the managerial nature of the responsibilities confided to the FHA, the court concluded that Congress intended to give the FHA total discretion to approve rent raises.

104. The court provided in its order for division of the tenants into classes based on incoine; a spokesinan would be permitted to appear for each group. It felt that this would minimize the burden on the agency. $347 \mathrm{~F}$. Supp. at 1206.

105. The court stated:

The questions involved in a rent increase do not turn on the resolution of specific factual issues on which the tenants as a group would have any special knowledge. The decision to raise rents requires rather the evaluation of complex financial data.

479 F.2d 1165, 1169 (2d Cir. 1973).

106. See note 103 supra.

107. It should be noted, however, that the rights created by these courts are limited to written comment, exactly as are those provided under the rulemaking provisions of the APA. The Burr court achieved this result by taking into account in its balancing 


\section{B. Analogy to the Right to Vote}

Additional support for judicial recognition of a due process right to participate in rulemaking may be found in D.C. Federation of Civic Associations, Inc. v. Volpe. ${ }^{108}$ In that case, Judge Skelly Wright used a substantive due process-equal protection approach rather than relying on procedural due process. ${ }^{109}$ By analogy to Supreme Court cases according special constitutional protection to the right to vote, ${ }^{110}$ he found that the plaintiffs' demand for participation in a decision as to the desirability of a proposed highway concerned a fundamental right of citizens to "effective participation in the political process . . . ."

Federation concerned a special statute passed by Congress mandating that work on a controversial and much-litigated project to build a bridge across the Potomac be commenced within thirty days after enactment of the statute. The statute appeared to exempt the project from otherwise applicable statutory provisions requiring local hearings on federally funded highway projects. Because Judge Wright found that the right to participate in sucl a learing was a fundamental right akin to the right to vote, lie reasoned that the statute had to be exammed in the light of a strict standard of review. Under this standard, if the statute were read to exclude District of Columbia residents from participation, while allowing participation by all other citizens in road projects in the 50 states, ${ }^{112}$ it would constitute an invidious discrimination, and would thus violate equal protection. ${ }^{113}$ Therefore, in order to save the statute, lie held that it did require a public hearing. ${ }^{114}$

equation the "legislative" nature of the facts. See text accompanying note 105 supra. It thus reintroduced a term which is vague and incapable of precise definition. See text accompanying notes 76-87 supra. The Appalachian court, while requiring only that the federal agency consider written comments, specifically left open the possibility that additional procedures inight be constitutionally required at the state level. The need for such procedures would depend not only on the nature of the facts at issue, but also the unagnitude of the threatened deprivation. These cases thus raise the issue of how the limits of the right to participate are to be determined once the distinction between rulemaking and adjudication as defined by the APA is abandoned. See part IV infra.

108. 434 F.2d 436 (D.C. Cir. 1970).

109. For a discussion of the relation between equal protection and due process as applied to "fundamental rights," see Developments in the Law-Equal Protection, supra note 7 , at $1130-31$.

110. 434 F.2d at 441-44, citing Reynolds v. Sims, 377 U.S. 533 (1964), and Harper v. Virginia Bd. of Elections, 383 U.S. 663 (1966). See also Kramer v. Union Free School Dist., 395 U.S. 621 (1969).

111. $434 \mathrm{~F} .2 \mathrm{~d}$ at 441 .

112. Id. at 439.

113. Id. at 443 .

114. Judge Bazelon, concurring, did not reach the constitutional issue, but argued that Congress did not intend to exeinpt the Department of Transportation from holding a public hearing in this instance. This contention was vigorously disputed by the dissenting judge. It seems fair to assume that Judge Bazelon inust have at least been influenced by the constitutional arguments, since the implications of the legislative history 
The court's analogy to the right to vote seems well-founded. Judge Wright noted that, if denied the right to participate, the affected citizens would have no means of influencing a decision which would vitally affect them:

These provisions [for public hearing] of Title 23 are the only form of direct citizen participation in decisions about the construction of massive freeways, decisions which may well have more direct impact on the hives of residents than almost any other governmental action. ${ }^{115}$

While noting that the analogy to the right to vote was not exact, the court reasoned: "[T]he similarities between voting and the public hearing are strong. The purpose and effect of a hearing may be the same as those of a vote. Both are designed to elicit the wish of the 'electorate.". "116

It might be argued that the lack of representation, and hence the very source and necessity for the analogy, is negated by the fact that the agency is appointed by elected representatives. ${ }^{117}$ However, this argument iguores the political realities on which Judge Wright implicitly rehes. ${ }^{118}$ It must be recognized that agencies, through their power to balance "legislative" facts in order to arrive at broad policy decisions, affect the lives of millions of people. In their exercise of this power, they are subject to no direct political pressure; indeed, they are often insulated froin it as a consequence of the general public's ignorance of most administrative decisions and proposals. Because of their internal structure, they respond more readily to powerful interests than to those of the ordinary citizen. ${ }^{118}$ In Reynolds $v$. Sims, ${ }^{120}$ the Supreme Court held that a state legislative districting system which weighted rural votes more heavily than urban votes constituted a denial of equal pro-

did not strongly support his statutory interpretation, Language in his opinion implies that this is the case. See id. at 448.

115. Id. at 441. Professor Cramton similarly argues that, because of the broad impact of rules, the rulemaking process should attempt to duplicate the representative and political process as fully as possible. Cramton, supra note 35 , at 531 .

116. 434 F.2d at 442. Charles Reich argues that "administrative agencies suggest a concept of a new multi-legislative democracy . ..." with a functional constituency composed of those affected by agency decisions. Reich, supra note 35, at 1259.

117. But see Kramer v. Union Free School Dist., 395 U.S. 621, 628 (1969):

The presumption of constitutionality and the approval given "rational" classifications in other types of enactments are based on an assumption that the institutions of ... government are structured so as to represent fairly all the people. However, when the challenge to the statute is in effect a challenge of this basic assumption, the assumption can no longer serve as the basis for presuming constitutionality. And, the assumption is no less under attack because the legislature which decides who may participate at the various levels of political choice is fairly elected (emphasis added).

118. See generally text accoinpanying notes 25-47 supra.

119. See text accompanyimg notes 28-33 supra.

120. 377 U.S. 533 (1964). 
tection. By analogy, a statutory exception such as section 553 (a) (2), which exacerbates the fact that the administrative system gives more weight to certain interests by partially or wholly excluding representatives of others, should also be unconstitutional. ${ }^{121}$

Confining recognition of the fundamental nature of the right to participate in the democratic process and the dangers of excluding certain classes froin that right to the legislative milieu alone ignores the fact that Congress has already delegated and will continue to delegate enormous amounts of power to agencies. Thus, unless Judge Wright's analogy is accepted, the right to vote is itself likely to become an illusion. The result may well be a system of administrative absolutism, since the amount of control the courts nay exert over such an enormous bureaucracy is limited. ${ }^{122}$

The imphications of Judge Wright's approach as to the APA are clear. It would be impossible to justify the 553(a)(2) exception so as to satisfy the strict equal protection standard. The breadth of the exception makes it inconceivable that all of the exempted rulemaking may be explained in terms of a compelling interest. Indeed, in response to recent atteinpts to amend section 553 by deleting the exception, proponents of the exception have depended on concepts that have lost vitality, such as the right-privilege distinction, or on arguments of excessive burden on agency facilities. The latter arguments are also invalid, since they apply equally to proceedings that are subject to notice and comment requirements. ${ }^{123}$

\section{IV \\ Parameters of the Right to Participate}

\section{A. Limitation}

Acceptance of the right to participate requires that the courts define its scope. Two preliminary issues arise: (1) when and by what inechamism may agencies limit participation to specified groups; and (2) when may agencies refuse to allow any participation.

121. Section 553 creates a right to participate in rulennaking, but the (a)(2) exception gives agencies discretion whether to allow public participation in a broad area of ruleinaking. The section thus dilutes the power of all those affected by excepted rulemaking to influence their own future. But cf. McDonald v. Board of Election Comm'rs, 394 U.S. 802 (1969).

122. To protect these interests from administrative arbitrariness, it is necessary, but not sufficient, to insist on strict judicial scrutiny of adininistrative action.

For judicial review alone can correct only the most egregious abuses. Judicial review must operate to ensure that the administrative process itself will confine and control the exercise of discretion.

Environmental Defense Fund, Inc. v. Ruckelshaus, 439 F.2d 584, 598 (D.C. Cir. 1971); see generally Cahn \& Cahn, The New Sovereign Immunity, 81 HaRv. L. REv. 929 (1968); Reich, supra note 35, at 1243-45.

123. See notes 66-72 supra and accompanying text. 
Both rationales for the right to participate, substantive due process-equal protection and procedural due process balancing, prohibit blanket exclusion of parties affected by agency rulemaking. Each, however, probably allows agencies to consider only "relevant" points of view. Under a procedural due process test, the plaintiff inust have a legally protected interest. ${ }^{124}$ Evidently, this simply restates the requirement of standing to sue. ${ }^{125}$ Under an equal protection analysis, parties clearly unqualified to represent the interests of those affected by a proposed rule might be denied participation. ${ }^{126}$ Participation inay. also be denied to those without substantial interest in the issues, if the category is narrowly drawn and if participation of those excluded would so overburden the administrative process that a conpelling interest nuight justify the exclusion. ${ }^{127}$

Recognition of a due process right to participate in rulemaking would not limit an agency's ability to refuse participation to all. Under the present terms of the APA, the rulemaking provisions do not apply "when the agency for good cause finds (and incorporates the finding and a brief statement of the reasons therefore in the rules issued) that notice and public procedure thereon are unpracticable, umiecessary, or contrary to the public interest." 128 Neither a balancing test nor a compelling interest test prohibits an agency showing that the effects of pub-

124. Board of Regents of State Colleges v. Roth, 408 U.S. 564 (1972).

125. Cf. National Welfare Rights Org. v. Finch, 429 F.2d 725 (D.C. Cir. 1970), in which the court held that since plaintiff, a group of welfare recipients, would have standing to seek review of the agency decision, it also had the right to intervene in an HEW hearing. The proceeding was for the purpose of determining whether federal welfare funds should be cut off because of the state's failure to follow federal requirements.

126. In many instances, such as in rulemaking affecting "the poor," it will be difficult to determine who actually represents the interests of groups which have heterogeneous and conflicting viewpoints. Representation for the Poor, supra note 33, at 522 . In rulemaking requiring notice and comment, the additional burden on the agency in accepting and considering written submissions from all those who care to respond is so minimal that there is little reason to atteinpt to determine the qualifications of those groups claiming representative status. Where oral presentation is required or desirable, however, the agency may have a compelling interest in selecting those who may participate in order to make the proceeding manageable. See Office of Communication of United Church of Christ v. FCC, 359 F.2d 994, 1005-06 (D.C. Cir. 1966). Such a possibility raises grave problems, however. Criteria for making such a selection are difficult to develop, leaving open the possibility that choices would be politically motivated. Exercise of such discretion should therefore be regulated by requiring formulation of clear and narrow standards, as difficult as such a task may appear. For an example of standards promulgated to regulate intervention in formal hearings before the $C A B$, see Palisades Citizens Ass'n, Inc. v. CAB, 420 F.2d 188, 193 (D.C. Cir. 1969).

127. Kramer v. Union Free School Dist., 395 U.S. 621, 632 (1969) (dictum). This test would include some groups who might be excluded under the procedural due process balancing test if they could show no injury in fact. See Association of Data Processing Service Orgs. v. Camp, 397 U.S. 150 (1970).

128. 5 U.S.C. $\$ 553(\mathrm{~b})(\mathrm{B})(1970)$; see also 5 U.S.C. $\$ 553$ (d) (3). These provisions are discussed in Public Participation, supra note 45, at 588-608. 
lishing the proposed rule and allowing public participation would be so damaging as to outweigh the benefit inlierent in a nore participatory process. This might be true, for example, in the case of emergency regulations or where publication of the rule before it became effective would defeat the very purposes for which it was being promulgated. ${ }^{128}$

\section{B. Beyond Notice and Comment: Ensuring Administrative Responsiveness}

The right to notice and comment participation in rulemaking should be accepted by the courts as the bare minimum generally required by due process. However, judicial recognition of the right to notice and comment participation would not eliminate the larger problem posed by the inherently unrepresentative nature of the administrative process: submission of written comments does not ensure that the agency will adequately consider, or even consider at all, the viewpoints of all those potentially affected by the proposed rule. ${ }^{130}$ This is particularly true in the case of those views not sufficiently represented within the agency. Courts nnust confront the problem of ensuring that the agency adequately considers the interests of all the public. Alternatively, the problem can be viewed as ensuring the right of all segments of the public to fair and equal trcatment in the rulemaking process.

Two possible approaches exist. The first defimes the scope of the right to participate to include procedural protections beyond those af-

129. Under the APA, the agency is also excused from rulemaking in the case of "interpretative rules, general statements of policy, or rules of agency organization, procedure, or practice." 5 U.S.C. $\$ 553(\mathrm{~b})(\mathrm{A})(1970)$. The assumption is that these are purely internal agency matters or subjects of little public significance, and therefore rulemaking is unnecessary and would unduly burden the agency. See generally Bonfield, Some Tentative Thoughts on Public Participation in the Making of Interpretative Rules and General Statements of Policy under the A.P.A., 23 AD. L. REv. 101 (1971).

130. One inethod by whicl an agency can effectively exclude siome segments of the public from participation in rulemaking is by publishing notice of the proceeding in such a way that many of those potentially affected never know of a proposed rule until it is put into effect. Professor Gellhorn notes that "there is a natural mcentive for agencies to limit public notice of agency proceedings by way of minimizing public paricipation . . . Gellhorn, supra note 60, at 402-03. In fact, since the APA presently requires notice only to be published in the Federal Register, 5 U.S.C. $\$ 553(\mathrm{~b})$ (1970), many decisions are made without any input by the general public. Compare Car. Gov'T CODE $\$ 11423$ (a) (West 1966), requiring, inter alia, publication in "such newspaper of general circulation, trade or industry publication, as the state agency shall prescribe." If the right to participate in rulemaking is protected by due process, failure to give adcquate notice is impermissible. Mullane v. Central Hanover Bank \& Trust Co., 339 U.S. 306 (1950); cf. Virgin Islands Hotel Ass'n v. Water \& Power Authority, 465 F.2d 1272 (3d Cir. 1972); see Gellhorn, supra note 60, at 398-99. For a discussion of methods of improving present notice procedures, see $i d$. at 399-403. 
forded by notice and comment. ${ }^{131}$ The second advocates exercise of judicial review in a manner that ensures that the agency has adequately considered the conflicting considerations at issue. These alternatives are not inutually exclusive, though the grant of additional procedural rights may affect the depth of review which a court might exercise. ${ }^{\mathbf{1 3 2}}$

\section{Additional Procedural Rights}

There may be several situations in which notice and comment fail to provide an effective right of representation. The factual issues involved may be so complex or technical as to require more than written submissions if the agency is to understand clearly the problems with the factual basis or potential impact of the proposed rule; ${ }^{133}$ the issues may be so controversial that at least an oral hearing is required; ${ }^{134}$ or those primarily affected by a proposed rule may be of limited educational background and therefore may need more than an opportunity to present written submissions in order to effectively inform the agency of their views. ${ }^{135}$ Cases such as Appalachian and Burr ${ }^{136}$ imply that the distinction between rulemaking and adjudication cannot alone determime the procedural rights of the public or affected parties. ${ }^{137}$ In each case, the procedure to be followed can only be determined by balancing the nature of the issues, the identities and capacities of the parties, and the effect that the procedural requirements will have on the administrative process. ${ }^{138}$ Alternatively, the requirements imposed by the rulemaking and adjudication sections of the APA could be viewed as baseline procedures. Since, under section 553, the agency may afford more than notice and comment participation, ${ }^{139}$ a court could re-

131. Such additional procedures may include oral presentation, presentation of witnesses, cross-examination of others' witnesses, and oral rebuttal of prior written submissions.

132. See text accompanying notes 165-67 infra.

133. See Mobil Oil Corp. v. FPC, 483 F.2d 1238 (D.C. Cir. 1973); International Harvester Co. v. Ruckelshaus, 478 F.2d 615, 630-31 (D.C. Cir. 1973); Appalachian Power Co. v. EPA, 477 F.2d 495 (4th Cir. 1973).

134. Walter Holm \& Co. v. Hardin, 449 F.2d 1009 (D.C. Cir. 1971); American Airlines, Inc. v. CAB, 359 F.2d 624, 631-32 (D.C. Cir. 1966) (dictum).

135. Burr v. New Rochelle Municipal Housing Authority, 347 F. Supp. 1202, 1206 n.5 (S.D.N.Y.), modified, 479 F.2d 1165 (2d Cir. 1973).

136. See text accompanying notes 96-106 supra.

137. Accord, International Harvester Co. v. Ruckelshaus, 478 F.2d 615, 651 (D.C. Cir. 1973) (Bazelon, C.J., concurring); Walter Holm \& Co. v. Hardin, 449 F.2d 1009 (D.C. Cir. 1971).

138. This approach is the same as that used in the adjudicative prior hearing cases, where the Supreine Court has clearly indicated that the nature of the required procedures will vary with the private and governmental interests involved. Morrissey v. Brewer, 408 U.S. 471 (1972); Bell v. Burson, 402 U.S. 535 (1971); Goldberg v. Kelly, 397 U.S. 254 (1970).

139. "After notice required by this section, the agency shall give interested persons 
quire additional procedural protections by holding that this power is subject to review for abuse of discretion. ${ }^{140}$ This approach would perinit the agency to rely on the APA to furnish procedural guidelines. In cases where notice and comment are inadequate to provide meaningful participation, however, the agency's failure to expand the rulemaking process to allow legislative or trial-type oral proceedings would afford sufficient grounds to challenge the resulting rule.

While the second alternative seems to give nnore weight to the judgment of Congress that rulemaking requires only notice and coinment, these approaches are functionally equivalent. Both would allow maximum procedural flexibility within the administrative process, since procedural requirements would be structured to meet the exigencies of the particular proceeding. At the same time, each approach would provide a check on agency discretion, thereby ensuring that those affected by agency action would have a fair and ineaningful opportumity to participate in the decisionmaking process. The showing required under either approach in order to prove a need for additional procedures would inost likely be the same. Presunably, a situation in which an administrative refusal to provide additional procedures would be an abuse of discretion would also constitute a demal of procedural due process, smce the basis of the complaint in either case should be that the right to effective participation was subverted..$^{141}$

Courts might be reluctant to use either approach to afford more than notice and comment participation when the agency itself has dechined to do so. ${ }^{142}$ Assuming that notice and comment are a constitu-

an opportunity to participate in the rule making through submission of written data, views, or arguments with or without opportunity for oral presentation." 5 U.S.C. \& 553 (c) (1970). See City of Chicago v. FPC, 458 F.2d 731, 743 (D.C. Cir. 1971), cert. denied, 405 U.S. 1074 (1972).

140. Clagett, Informal Action-Adjudication-Rulemaking: Some Recent Develop. ments in Federal Administrative Law, 1971 DuKE L.J. 51, 73 (1971); Note, The Judicial Role in Defining Procedural Requirements for Agency Rulemaking, 87 HARV. L. REv. 782, 796-98 (1974) [hereinafter cited as The Judicial Role]. See also L. JAFFE, JUDICial CONTRol of AdMinistrative Action 566-69 (1965).

141. A decision that failure to provide additional participation violated due process would seem to have no inore precedential value than a decision that such a denial was an abuse of discretion. Either decision would depend upon the circumstances of the individual proceeding. Its impact would extend only to substantially similar proceedings by the agency involved.

142. See Mobil Oil Corp. v. FPC, 469 F.2d 130, 140 (D.C. Cir. 1972), cert. denied, 412 U.S. 931 (1973) ("The Commission has satisfied [the] minimal procedural requireinents, and it is not for us to require more, whatever may be our views on the wisdom of this policy.").

Whether courts should impose procedural requirements beyond those already required by the APA in rulemaking as a matter of due process or of statutory construction is becoming a subject of much debate and controversy. See generally Verkuil, Judicial Review of Informal Rulemaking, 60 VA. L. REv. 185, 234-42 (1974); Wright, The 
tional minimum, it may be questioned whether due process ever requires more. ${ }^{143}$ A court might well reason that, even granting the unrepresentative nature of the agency, it must be presumed to act in good faith. If presented with all viewpoints through the minimum procedures of section 553, it should be assumed that the agency will consider each on its merits. The agency itself, after having considered the written submissions, should be able to decide if further clarification is necessary and what procedures should be used to obtain it.

A court making this argument would be likely to emphasize the disadvantages flowing from either the due process approach or the abuse of discretion reasoning. Under either rationale, a judicial decision mandating additional procedural requirements undermines the guidelines supplied by the APA. Sucli decisions may lead to administrative uncertainty as to the applicable procedural requirements, especially since the issue can only be conclusively decided on a case by case basis. Such a result destroys the uniformity and certainty that were express congressional goals in drafting the APA. ${ }^{144}$ As a result, agencies may feel compelled to adopt elaborate rulemaking procedures that will unnecessarily encumber the rulemaking process. ${ }^{145}$ If they do not, they will leave themselves open to a subsequent judicial determination that further proceedings are required which would entail remand to the agency, invalidation of the rule, and consequent delay and uncertainty.

While this argument has strong appeal, it does not override the need for restrained judicial supervision of the procedural fairness of rulemaking proceedings. Fundamental interests may be affected by

Courts and the Rulemaking Process: The Limits of Judicial Review, 59 CORNELL L. Rev. 375 (1974); The Judicial Role, supra note 140.

143. In a recent article, Judge J. Skelly Wright argues that, in the rulemaking context, due process never requires more than notice and comment proceedings, since the issue is not fairness to individuals, but rather fairness to the public generally. Wright, supra note 142, at 385-86. Judge Wright, however, is discussing economic and environmental regulation, affecting segments of the public which are generally well organized, well financed, and well represented on agency staffs. In other contexts, such as a rent raise in a housing project or an urban renewal funding decision which may displace people unable to find other housing, the equities may be quite different. Moreover, even in the area of economic regulation, if it can be objectively stated that the agency could not adequately consider the views of those substantially affected in the form of written submissions, whether because of the complexity of the issues or for other reasons, then it is difficult to see how the agency may act in the public interest. By definition, it is acting on the basis of incomplete and possibly inaccurate information.

144. Untted States Department of Justice, Attorney General's Manual on THE AdMInistrative Procedure ACt 9 (1947).

145. See Wright, supra note 142 , at 386-88. In cases where the agency lias the choice of proceeding by rule or by individual adjudication, judicial activism on this front may discourage use of rulemaking, and increase tremendously the burden on the agencies. Cf. American Airlines, Inc. v. CAB, 359 F.2d 624, 629 (D.C. Cir.), cert. denied, 385 U.S. 843 (1966). 
administrative actions, ${ }^{146}$ and great difficulties inhere in the determination of whether sufficient weight has in fact been given to those viewpoints not otherwise represented on the agency staff. In some instances, unless the court itself is to get involved in issues of great techmical complexity or controversial impact, additional procedural requirements inust be imposed to ensure that "the agency provides a framework for principled decisionmaking." 147 In other instances, ensuring that the agency adequately considers certain viewpoints requires that assumptions and traditional orientations of agency staff be challenged and rebutted more effectively than is possible through written cominent.

Finally, affording additional procedures in agency proceedings furthers the underlying principle that it should be the agency, rather than the court, which inakes the substantive decision after considering all available and necessary data and arguments. ${ }^{148}$ Unless courts are to defer substantially to administrative expertise, ${ }^{140}$ the alternative to procedural review is substantive judicial review of a rule, even though the agency has not adequately considered all the arguments that might be raised were broader participation allowed. This raises dangers of judicial usurpation of the agency's role. A doctrine which allows courts to protect private and public interests from arbitrary administrative encroachment by broadenimg participation within the administrative process itself will provide a safety valve for due process concerns while eliminating the temptation to second-guess the administrative decision. ${ }^{150}$

146. International Harvester Co. v. Ruckelshaus, 478 F.2d 615, 651 (D.C. Cir. 1973) (Bazelon, J., concurring).

147. Id. at 651, citing Environmental Defense Fund, Inc. v. Ruckelshaus, 439 F.2d 584 (D.C. Cir. 1971). For criticism of Judge Bazelon's argument, see Wright, supra note 142 , at $389-90$.

148. Cf. Office of Communication of the United Church of Christ v. FCC, 359 F.2d 994 (D.C. Cir. 1966); Scenic Hudson Preservation Conf. v. FPC, 354 F.2d 608, 612 (2d Cir. 1965), cert. denied, Consolidated Edison Co. v. Scenic Hudson Preservation Conf., 384 U.S. 941 (1966). See also Walter Holm \& Co. v. Hardin, 449 F.2d 1009 (D. C. Cir. 1971).

149. This has been increasingly disfavored. See generally Verkuil, supra noto 142, at 206-10.

150. For an extreme example of what may occur if judges feel unable to require more than written submissions in rulemaking, see Buckeye Power, Inc. v. EPA, 481 F.2d 162 (6th Cir. 1973). The court there held that federally-approved state air quality plans could be collaterally attacked in state enforcement proceedings. It reasoned that, under the Clean Air Act, the Administrator of the EPA was bonnd only by the rulemaking requirements of section 553 of the APA. Therefore, public utilities were unable to effectively raise their "complex and intricate claims of high cost-benefit, technological infeasibility and resource unavailability" before the state plan was approved. In holding that such claims could be raised as a defense in enforcement proceedings, the court ignored the fact that state hearings in which these claims could be presented were required 


\section{Judicial Review}

Admitting the adequacy of notice and comment, or assuming that, in cases where such participation is inadequate, additional procedural rights have been granted, the proper role of the courts in reviewing administrative decisionmaking remains to be ascertained. ${ }^{151}$ Under the APA the reviewing court must determine, on the basis of the "whole record," 152 whether the rule is "arbitrary, capricious, an abuse of discretion, or otherwise not in accordance with law."153 This language does not define the degree of deference a court should accord to administrative action. The resolution of this issue may well depend on the importance one attaches to whether those affected by the rule have participated in its formulation.

Relying on administrative expertise as a rationale, courts in the past gave extreme deference to agency findings and conclusions, strik-

before submission of the plan to the EPA; it also ignored clear statutory language that such claims could not be subsequently raised as a defense. Compare Appalachian Power Co. v. BPA, 477 F.2d 495 (4th Cir. 1973), in which the court held that, assuming the adequacy of the procedure used in the state hearing and assuming that the Administrator reviewed the record of the state hearings, due process requirements were met. The court imposed no more than would section 553 on the Administrator, while implying that procedures in addition to written comment could be required at the state level. Id. at 503. It thereby effected a compromise between the considerations of administrative efficiency and procedural fairness.

151. See generally Verkuil, supra note 142.

152. 5 U.S.C. $\$ 706$ (1970). Section 4 of the APA requires formal rulemaking procedures only "[w] hen rules are required [by an independent statute] to be made on the record after opportunity for an agency hearing." Id. \$ 553(c). See United States v. Allegheny-Ludlum Steel Corp., 406 U.S. 742 (1972). In "informal" or notice and comment proceedings, the agency is nierely required to "incorporate in the rules adopted a concise general statement of their basis and purpose." 5 U.S.C. \& 553(c) (1970). The legislative history indicates that the whole record requirement was intended only to ensure that a court using the substantial evidence test of section 706(2)(E) to review an agency decision made after formal hearing would consider evidence in the record adverse to, as well as supportive of the administrative result. See S. REP. No. 752, 79th Cong., 1st Sess. 28 (1945); H.R. ReP. No. 1980, 79th Cong., 2d Sess. $45-46$ (1946). Since, in informal rulemaking, the decisionmaker is not restricted to evidence produced by the parties, it is quite likely that the administrative record will not reveal all the factors affecting his decision. However, some courts have construed the APA to require review of the whole administrative record, even when using the arbitrary and capricious standard. See, e.g., Appalachian Power Co. v. EPA, 477 F.2d 495 (4th Cir. 1973). The Supreme Court adopted this view in Citizens to Preserve Overton Park, Inc. v. Volpe, 401 U.S. 402, 420 (1971). See Verkuil, supra note 142, at 205-06.

153. 5 U.S.C. $\$ 706(2)(A)(1970)$. The court must also "hold unlawful and set aside agency action ... found to be . . . contrary to constitutional right, power, privilege, or immunity," id. \$ 706(2)(B), "in excess of statutory jurisdiction, authority, or limitation, or short of statutory right," $i d . \$ 706(2)(C)$, or "without observance of pro cedure required by law," id. $\$ 706(2)(D)$. A court reviewing adjudicative decisions or formal ruleinaking must determine whether the agency action is supported by substantial evidence on the basis of the record. Id. $\S 706(2)(\mathrm{B})$. 
ing them down only when they were so arbitrary as to be irrational or when the agency had gone beyond its statutory authority. ${ }^{154}$ This judicial attitude parallels that underlying the rational basis test used when reviewing economic legislation. ${ }^{165}$ The assumption is that administrative agency expertise serves as a substitute for the safeguards inherent in the political process which form the basis for judicial deference to legislative decisionmaking.

Judical deference to administrative expertise is no longer viable as a blanket rule $\mathrm{e}^{156}$ in light of the fundamental societal interests regulated by administrative action, ${ }^{157}$ the relative isolation of agencies from the political processes, ${ }^{158}$ and the lack of adequate representation of

154. Mobil Oil Corp. v. FPC, 469 F.2d 130 (D.C. Cir. 1972), cert. denied, 412 U.S. 931 (1973); Udall v. Washington, Virginia and Maryland Coach Co., 398 F.2d 765, 769 (D.C. Cir. 1968); Superior Oil Co. v. FPC, 322 F.2d 601 (9th Cir. 1963), cert. denied, 377 U.S. 922 (1964).

155. See note 7 supra.

156. The judicial attitude may depend on the agency involved and the interests at stake in rulemaking. See, for example, the extreme deference accorded to regulations of the Federal Reserve Board promulgated under the Truth in Lending Act in the face of contentions that the Board had exceeded its statutory authority. Mourning v. Family Publications Service, Inc., 411 U.S. 356 (1973).

157. We stand on the threshold of a new era in the history of the long and fruitful collaboration of administrative agencies and reviewing courts. For many years, courts have treated administrative policy decisions with great deference ....

... As a result of expanding doctrines of standing and reviewability, and new statutory causes of action, courts are increasingly asked to review administrative action that touclies on fundamental personal interests in life, health, and liberty. These interests have always had a special claim to judicial protection ....

Environmental Defense Fund, Inc. v. Ruckelshaus, 439 F.2d 584, 597-98 (D.C. Cir. 1971) (footnotes omitted).

158. [R]ule-making is frequently spoken of as a "quasi-legislative" function. While this is an accurate description, it means that, although the process leading to the promulgation of a rule frequently resembles the legislative process and although a rule frequently has an impact similar to that of a statute, rulemaking is not fully equivalent to the action of the legislature. Clearly, rulemaking is the action of a body subordinate to the legislature. That the same deference accorded "findings" of the legislature is not to be given the findings of the Commission is implicit in the law governing delegation of authority.

City of Chicago v. FPC, 458 F.2d 731, 742 (D.C. Cir. 1971) (footnotes omitted), cert. denied, 405 U.S. 1074 (1972). The "law governing legislative delegation of authority" relied on by the court, while once requiring legislatures to set definite statutory staudards when delegating authority to make rules, now permits delegation without auy standards other than the requirement that the agency act "in the public interest." See generally $1 \mathrm{~K}$. Davis, supra note 9, ch. 2 (1958, Supp. 1970); L. JAFFe, supra note 140, ch. 2 (1965); Jaffe, An Essay on Delegation of Legislative Povver (pts. I-II), 47 ConUM. L. REv. 359, 561 (1947). In the absence of special constitutional considerations, and perhaps even in cases involving such considerations, cf. Umited States v. Robel, 389 U.S. 258, 269 (1967) (Brennan, J., concurring), the non-delegation doctrine has been supplanted by other means of preventing administrative arbitrariness. The court is correct, however, in emphasizing that delegation permits policymaking by agencies removed from 
all affected interests in internal agency decisionmaking processes. ${ }^{\mathbf{1 5 9}}$ Many courts, including the Supreme Court in Citizens to Preserve Overton Park, Inc. v. Volpe, ${ }^{160}$ have rejected the traditional hands-off attitude and have insisted instead on "probing, in-depth review" even under the arbitrary and capricious standard. ${ }^{161}$ This entails determining "whether the decision was based on a consideration of the relevant factors and whether there has been a clear error of judginent." ${ }^{162}$

the mainstream of the political process in which policy decisions were formerly expected to be made. Because this is true, substantial judicial supervision is required to determine if, in fact, the public interest has been served by reasoned decisionmaking.

159. See text accompanying notes 28-33 supra. In Autoinotive Parts \& Accessories Ass'n v. Boyd, 407 F.2d 330 (D.C. Cir. 1968), plaintiffs, manufacturers and dealers of auto accessories, raised the contention that the rulemaking procedure was invalid because there were no representatives of their interests on the advisory council which participated in the formulation of the rule. Id. at 334 n.5. The court disposed of this argument by stating that the Secretary had full discretion im making appointments to the Council. Since similar attacks on the make-up of agency staffs would likely receive this same disposition, the lack of representation must be remedied by a right to participate, by careful judicial review, or by a combination of the two.

160. 401 U.S. 402 (1971). For discussions of this case and its impact, see Federal Administrative Law Developments-1971, 1972 DUKE L. J. 115, 317 (1972); The Supreme Court, 1970 Term, 85 Harv. L. Rev. 315 (1971); Note, Citizens to Preserve Overton Park, Inc. v. Volpe: Environmental Law and the Scope of Judicial Review, 24 STAN. L. REV. 1117 (1972) [hereinafter cited as Environmental Law].

161. 401 U.S. at 415 . The case concerned federal approval, necessary to secure federal funds, of a highway route planned to go through a park. While the Secretary of Transportation was exempt from notice and hearing requirenents under scction 553 (a) (2) of the APA, the state was required to hold public hearings and forward the transcript to the Secretary. The court's decision therefore cannot be said to apply only when there has been no public participation in the administrative decision.

162. Id. at 416. The Supreme Court in Overton Park not only advocated stricter scrutiny of the exercise of agency discretion, but it also substituted its statutory interpre. tation for that of the agency in a case where the legislative history was far from clear. See The Supreme Court, 1970 Term, supra note 160, at 323-25. It thereby precluded any consideration by the Secretary of greater cost and dislocation problems presented by other routes when determining whether a route through a park was justified. The Court held that the Secretary could approve such a route only if other routes presented "unique problems." It has been suggested that the Court felt the need to supply narrow standards in order to counterbalance what it saw as the innate bias of the Department of Transportation in favor of highways over parks. Environmental Law, supra note 160, at 1126 n.56.

Courts may substitute their judgment for that of the agency by characterizing an issue as a question of law, rather than one of fact, much as the Court did in Overton Park, in order to ensure consideration of interests against which the agency may be biased. However, most courts have been reluctant to do so, especially when they feel that agency expertise is involved; rather, they have strictly reviewed agency decisions only to ensure that there was adequate procedural compliance with statutory maudates and sufficient factual basis for the decision. See, e.g., Norwalk CORE v. Norwalk Redevel. Agency, 395 F.2d 920 (2d Cir. 1968); Western Addition Comm. Org. v. Romney, 320 F. Supp. 308 (N.D. Cal. 1969), vacating 294 F. Supp. 433 (N.D. Cal. 1968), discussed in McGee, Urban Renewal in the Crucible of Judicial Review, 56 VA. L. Rev. 826, 87379 (1970). Compare Scenic Hudson Preservation Conf. v. FPC, 453 F.2d 463 (2d Cir. 1971), with Scenic Hudson Preservation Conf. v. FPC, 354 F.2d 608 (2d Cir. 1965). 
This approach may be criticized, especially since it tends to engulf the courts in technical questions with which an agency is arguably better able to cope. ${ }^{163}$ It also presents the danger that, in spite of disclaimers, courts will substitute their judgement for that of the agency. ${ }^{164}$ However, courts deal with technical questions in a myriad of cases not involving administrative action. Given that such review is not beyond judicial capabilities, rehance on judicial restramt protects against administrative arbitrariness better than reliance on administrative good faith and expertise.

Once a court determines, however, that those affected by agency decisionmaking have had sufficient opportunity to participate in the administrative proceeding, it may feel justified in deferring to the agency's final decision rather than engaging in strict scrutiny of the resulting rule. Allowing participation through notice and comment, with additional procedures when required, minimizes the differences between legislatures and agencies. Participation, as a substitute for elections and checks and balances inherent in the legislative process, arguably should provide sufficient protection to those affected by rulemaking to allow the court to extend the same deference to the agency that it would to the legislature.

This position assumes strict judicial oversight of administrative procedural matters. Simce strict procedural review requires substantial judicial tinkering with agency discretion as well as with the procedural guidelines supphed by the $\mathrm{APA},{ }^{165}$ it may not be desirable. In the absence of such judicial assurance of adequate participation, however, restriction of the scope of review will result in almost unchecked agency discretion. Further, the argument that participation justifies a lesser degree of judicial scrutiny also assumes that, given adequate opportumity, groups or individuals affected by a proposed rule will be able to represent their views before the agency. It thus fails to consider practical problems of expense, lack of familiarity with administrative processes, and lack of cohesiveness among affected groups. Finally, it is impossible to ensure that agencies will consider equally all viewpoints presented to them. Those interests represented on agency staffs are likely to receive greater empliasis than interests whose only support

163. While we remain diffident in approaching problems of this techuical complexity, the necessity to review agency decisions, if it is to be more than a meaningless exercise, requires enough steeping in technical matters to determine "whether the agency has exercised a reasoned discretion."

Portland Cement Ass'n v. Ruckelshaus, 486 F.2d 375, 402 (D.C. Cir. 1973). See also

International Harvester Co. v. Ruckelshaus, 478 F.2d 615, 647-48 (D.C. Cir. 1973).

164. Verkuil, supra note 142, at 209-10.

165. See text accompanying notes 144-45 supra. See also JAFFE, supra note 140 , at $565-69$. 
comes from outside groups. Review should be directed to this danger. A decision which ignores the views of those substantially affected may well be arbitrary and capricious; ; ${ }^{166}$ an agency which acts on the basis of internal bias at least fails to conform to inherent or explicit statutory requirements that it act in the public interest. ${ }^{167}$ More than a bow to agency expertise is needed to ensure that agency decisions conform to this standard, even where there has been public participation in formulation of the decision.

\section{CoNCLUSION}

In light of Congress' increasing reliance on administrative rulemaking and the resulting power of an ever-growing bureaucracy, the courts will inevitably be faced with demands to extend due process to ruleinaking as well as adjudicative administrative procedures. The rulemaking-adjudicative distinction when applied to inherently unrepresentative administrative bodies cannot justify a refusal to do so. The courts have already begun to abandon their attitude of unquestioning deference to administrative expertise and to realize the enormous power to affect individual lives which is concentrated in administrative agencies. The deinand for entry into the planning process will inost certainly grow and will have to be satisfied. The result will be to deinocratize the administrative process and to more closely align political realities with political idealism.

Of course, this will not solve all the problems. One issue will probably become pressing: who is to represent the public? Group. representation will be a necessity for effective participation, and standards will have to be set to determine who is truly representative. Alternatively, some of these groups might be incorporated into the planning process, or an agency might be established whose sole function would be to act as a watchdog and representative for the public. All of these proposals have been suggested. ${ }^{168}$ Although the courts cannot elaborate complex schemes of participation, they can, and should outline the minimum requirements of a right to participate. The responsibility would then shift to Congress, which must effectuate the courts' mandate. The greater the thoughtfulness and enthusiasin brought to this project, the healthier our society will be in the future.

166. Appalachian Power Co. v. EPA, 477 F.2d 495 (D.C. Cir. 1973), citing Citizens to Preserve Overton Park v. Volpe, 401 U.S. 402 (1971) and Hanly v. Mitchell, 460 F.2d 640 (2d Cir. 1972).

167. See Scenic Hudson Preservation Conf. v. FPC, 354 F.2d 608 (2d Cir. 1965); Office of Communication of the United Church of Christ v. FCC, 359 F.2d 994 (D.C. Cir. 1966).

168. See, e.g., Representation for the Poor, supra note 33; Cahn \& Cahn, supra note 122; Reich, supra note 35. 